\title{
Board of Directors Network Centrality and Environmental, Social and Governance (ESG) Performance
}

\author{
Maretno A. Harjoto \\ Professor of Finance \\ Pepperdine Graziadio Business School (PGBS) \\ Pepperdine University \\ Malibu, CA 90263-4100 \\ USA \\ Email: maretno.harjoto@pepperdine.edu \\ Tel. 001 (310) 506-8542 \\ Yan Wang \\ Associate Professor of Accounting and Finance \\ Nottingham Business School \\ Nottingham Trent University \\ 50 Shakespeare Street \\ Nottingham \\ NG1 4FQ \\ UNITED KINGDOM \\ Email: yan.wang@ntu.ac.uk \\ Tel. $44(0) 1158488278$
}

\section{Acknowledgment}

The authors acknowledged the contributions from two anonymous reviewers for their constructive comments and recommendations. The authors thank the Editor, Gabriel Eweje, for his consideration. Harjoto acknowledges the Denney Academic Chair 2019-2021 research endowment for the financial support and release time for this research project. 


\title{
Board of Directors Network Centrality and Environmental, Social and Governance (ESG) Performance
}

\begin{abstract}
Purpose: Drawing from social capital, social network theory of stakeholder influence, and stakeholder management, this study examines the relationship between board network centrality and firms' environmental, social and governance (ESG) performance.

Design/methodology/approach: Using social network analysis, we construct five board network centrality, namely degree centrality (the number of connections), closeness centrality (distance among firms), eigenvector centrality (the quality of connections), betweenness centrality (how often a firm sits between two other firms), and the information centrality (the speed and reliability of information), as measures of board access for social capital and timely information.
\end{abstract}

Findings: Using a sample of non-financial firms listed in the UK FTSE 350 index from 2007 to 2018, we find that board networks, measured by degree, closeness, eigenvector, betweenness, and information centrality, have positive influence on firms' environmental, social and governance (ESG) performance. Furthermore, our findings show that there is a non-linear relationship between board networks and ESG performance and this relationship is stronger in the sectors where firms that have high product market concentration and high percentage of women board members.

Originality: This study unveils that strong board network centrality brings higher social (reputational) capital and information advantages to the firm to effectively, timely, and accurately deal with the pressures from stakeholders (stakeholder management), which leads to better environmental, social, and governance (ESG) performance.

Keywords: board network centrality; social network analysis; stakeholder management; ESG performance; non-linear 


\section{Introduction}

In the digital and social media era where the speed and ease of connectivity are significantly faster, informal social and professional networks have become the essential part of corporate strategic operations (Collins and Clark, 2003; Zaheer and Bell, 2005). Extant studies have demonstrated that a firm's networks or often referred to a firm's "social capital" have been found to enhance innovation (Ahuja, 2000; Tsai and Ghoshal, 1998), knowledge transfer (Burt, 1992; 1997; Inkpen and Tsang, 2005; Koka and Prescott, 2002), intellectual capital (Nahapiet and Ghoshal, 1998), and efficiency (Baker, 1990; Burt, 2000). Adler and Kwon (2002) define social capital as "the goodwill (sympathy, trust, and forgiveness) that others have offered us is considered as a valuable resource" (pg. 18). Furthermore, a firm's social capital is largely facilitated by their direct and indirect links to other firms through director interlocks. Empirical studies also find that a firm's networks built from its board of directors contribute to the boards' ability to make more effective strategic decisions (Carpenter and Westphal, 2001; Thorgren, Wincent, and Anokhin, 2010). Our study extends this research stream by focusing on the board of directors' networks and the relationship between board networks and firms' environmental, social, and governance (ESG) performance.

Existing literature has examined the impact of social and professional networks of the top executives and board of directors on firms' financial performance and generally find that there is a positive relationship between them (e.g., Chahine and Goergen, 2013; Chuluun, Prevost, and Puthenpurackal, 2014; Horton, Millo, and Serafeim, 2012; Larcker, So, and Wang, 2013). Recent studies have also found that there is a positive relationship between US firms' alliance network centrality and corporate social performance (Macaulay et al., 2018; Vo, Le and Kim, 2020). Muthuri, Matten, and Moon (2009) also find a positive relation between the networks built from employees' volunteerism and firms' corporate social performance on three UK multinational firms. We extend this strand of literature and focus on the board of directors 
for UK firms because of two reasons. First, the structure of board in the UK consists of executive and non-executive directors who work closely together and are collectively responsible for the firm performance (e.g., Conyon and Peck, 1998; Elmagrhi, Ntim, and Wang, 2016; Hopt and Leyens, 2004; Van Veen and Elbertsen, 2008). Bainbridge (2017) indicates that the collective responsibilities of the board in the UK has increased the importance and the influence of board of directors' monitoring and advising roles on firm performance. Second, the informal professional and social networks in the UK have been considered as deficient relative to other developed countries such as the US (e.g., Conyon and Muldoon, 2006; Letki, 2008; Pichler and Wallace, 2007; Useem, 1984). Thus, our study highlights the importance of board networks for the UK firms.

In the wake of corporate scandals and the 2007 global financial crisis, corporate social responsibility performance has drawn much attention among top executives, investors, and academics. The United Nations Global Compact (2017) indicates that there are over 9,000 companies and 4,000 non-businesses across 161 countries have taken serious commitments to address social issues, specifically actions to improve the environment, social, and governance (ESG) performance. More specifically, UK has considered corporate social responsibility or ESG performance seriously since UK was the first country in the world to appoint a Minister for Corporate Social Responsibility in March 2000. However, similar to most of other developed countries (e.g., United States), ESG activities in the UK are mostly practiced by large multinational corporations at which the power of shareholders' interests seems to dominate the interests of non-investing stakeholder (Brammer, Jackson, and Matten, 2012; Goergen et al., 2019; Kinderman, 2012; Wang et al., 2019). Thus, researchers have argued that the role of board of directors in the UK firms has become increasingly critical to represent the interests from the non-investing stakeholders along with the shareholders' interests (Aguilera, 
2005; Aguilera et al., 2006; Elmagrhi, Ntim and Wang, 2016; Hillenbrand, Money, and Ghobadian, 2013; Money and Schepers, 2007).

Our study argues that having board of directors with strong networks would allow directors to draw the resources embedded within each director's social and professional networks, which are accessible through direct and indirect professional ties (Booth-Bell, 2018; Jang, Chung and Woo, 2019; Kacanski, 2019; Krenn, 2017). These resources increase firms' information advantages to satisfy the needs of and to address the pressures from non-investing stakeholders, thus leads to better ESG performance. Drawing from the social capital (Adler and Kwon, 2002) and social network theory of stakeholder influence (Rowley, 1997) and stakeholder management theory, we argue that board networks represents valuable social capital that can be mobilized to enhance firms' ability to gain faster and more accurate information to satisfy the needs of the stakeholders (Freeman, 1984; Donaldson and Preston, 1995; Rowley, 1997). We focus on board of directors because they have broader networks through their services on multiple companies (interlocking) and the board of directors have advising and monitoring roles, which lead to firms' tangible strategic actions (Forbes and Milliken, 1999). We argue that firms with stronger board networks have higher ability to tap information from their networks to understand recent developments to address the pressures from various stakeholders more quickly and more effectively and therefore leads to better ESG performance.

\section{Literature Review and Hypotheses Development}

Board networks and corporate social performance

The theory of social capital has been developed from sociology and psychology literature where researchers have recognized the value of networks as irreplaceable social capital (Bourdieu, 1972; 1985; Burt, 1987; Jacobs, 1961). Recently, management and business 
literature have adopted social capital theory to explain the benefits of networks (Adler and Kwon, 2002; Seibert, Kraimer, and Liden, 2001; Woolcock and Narayanan, 2000). More specifically, the social capital theory has been used to explain the information channels among board of directors (Horton et al., 2012; Larcker et al., 2013; Chuluun et al., 2014) in relation to corporate financial performance.

The informal social and professional networks are usually built based on commonalities among the network participants (e.g., having similar careers, professions, etc.). Members of the networks can tap into the knowledge shared among members within the networks to advance their knowledge, know how, and more importantly critical and timely information that allow the members to make more effective decision-making (Carpenter and Westphal, 2001). Social and professional networks differ from others because they can maintain their power and can insulate themselves from traditional hierarchical organizational power. Within the management discipline, informal networks have been conceptualized using either a social capital or a social exchange that effective workplace relationships build mutual reciprocity that delivers benefits to all stakeholders (Adler and Kwon, 2002; Oh, Chung, and Labianca, 2004; Sparrowe et al., 2001).

Adler and Kwon (2002) define the "social capital" as resources available to actors that is a function of their "location" within the networks of their social relations. We argue that board members who hold multiple positions in other companies have advantageous location within their social and professional. Woolcock (1998) and Woolcock and Narayanan (2000) specifically define the "social capital" as having access to information that are available only if ones belong to the networks. Drawing from the resource theory of social exchange, Foa and Foa $(1974 ; 1980)$ also indicate that the value of social capital specifically focuses on having access to critical information exchange within the social networks. Therefore, we argue that board with greater networks have greater information advantages than boards with less 
networks. Therefore, the relative position of board in the network plays a critical role on their ability to gain access toward more accurate and timely information, especially with respect to addressing the stakeholders' needs. The firms' ability to effectively address the stakeholders' needs will result in higher ESG performance (Swanson and Orlitzky, 2018).

Extant literature has found that corporate governance effectiveness, monitoring, and corporate decision-making are influenced by board of directors' informal professional and social networks (Alipour et al., 2019; Cohen, Frazzini, and Malloy, 2008; Harjoto, Laksmana and Yang, 2019; Hochberg, Ljungqvist, and Lu, 2007; Kuhnen, 2009; Seidel, Polzer, and Stewart, 2000). For instance, Cohen et al. (2010) find that sell-side analysts who have educational connections with companies' board of directors tend to perform better in their stock recommendations. Renneboog and Zhao (2011) indicate that directors' networks are important to firms because through its directors a firm can "gain access to information, even prior to its public disclosures". Directors with stronger networks can also increase the firms' reputation in the society due to their close network relationships with key stakeholders (e.g., employees' organization, regulatory agencies, etc.). Macaulay et al. (2018) find a positive relationship of women boards and outside directors as proxies for board network alliance and firms' ESG performance. We extend the existing literature by examining the relationship between board network centrality and ESG performance.

Rowley (1997) develops the theory of stakeholder influence based on the social network structure and argues that network theory allows us to examine system of a dyadic (network or cobweb) of interactions, influences, and the interdependencies among stakeholders and the firm. More importantly, he argues that the centrality of firms' corporate actors (i.e., board of directors) in the network relative to others increases the firms' ability and effectiveness to accommodate and to respond to stakeholders' demands (stakeholder management). 
Insert Figure 1 about here

We illustrate the interconnections between social capital and social network of stakeholder influence and stakeholder management in Figure 1. We argue that boards with higher networks can bring social capital to the firm. More specifically, board networks allow the firms to have access to high quality information (information advantage). Thus, firms with boards that are in a central position in the network may have better understanding of the stakeholders' needs that allow the firms to have closer connections to various stakeholder groups. As indicated by arrow A in Figure 1, the social capital theory (Adler and Kwon, 2002) and the social network of stakeholder influence theory (Rowley, 1997) both explain the importance of board networks for firms to manage the pressures from stakeholders. Furthermore, closer connections allow them to have a faster and more accurate understanding of the networks, coalitions, and complex interconnections of various stakes among stakeholders. Directors with higher (more essential) network centrality can bring greater insights for stakeholder management to the firms to construct a rational stakeholder map and are able to strategically, effectively, and more efficiently address the pressures and the interests of their stakeholders (arrow B of Figure 1). The firms' competitive advantages to effectively address their stakeholders' demands translates into higher ESG performance (arrow C of Figure 1). Firms with well-connected board of directors also have higher social and reputational capital at stake and they have stronger incentive to protect their social and reputational capital (Adler and Kwon, 2002; Seibert et al., 2001; Woolcock and Narayanan, 2000). Corporate social responsibility and philanthropic activities can generate positive moral capital that provides the “insurance like" to protect firms' reputational (social) capital (Godfrey, 2005; Godfrey, Merrill 
and Hansen, 2009). Therefore, firms with well-connected boards also have stronger incentives to support firms' social responsibility activities to protect their own reputational capital and maintain their central positions in the network. Thus, we expect that board with stronger networks, which represents firms' reputational (social) capital, tend to have higher ESG performance. We formulate the following hypothesis:

Hypothesis: Firms that have board of directors with higher network centrality have higher ESG performance.

\section{Research Design}

Data and sample

Our sample composed of 203 non-financial firms listed on the London Stock Exchange FTSE 350 index from 2007 to 2018. Based on these 203 UK non-financial firms, we collect our data from multiple sources. First, we gather information on board of directors from the BoardEx database, which provides a comprehensive information on directors of public listed firms in the UK We use this information to construct five measures of board networks, namely degree centrality, eigenvector centrality, closeness centrality, betweenness centrality and information centrality. Second, the data on board size, board independence, CEO tenure, CEO age, CEO education, CEO gender, the percentage of women board members and busy board are obtained from BoardEx. Third, environmental, social, and corporate governance (ESG) data is manually collected from the Bloomberg. Bloomberg started to report the ESG scores since 2007 (Grewal, Hauptmann, and Serafeim, 2017). Finally, we collect firms' financial information and institutional ownership data from the Bloomberg that provides definitive source of company information for the UK firms. After deleting missing observations, our final sample consists of 199 UK non-financial firms that are listed on the FTSE 350 index with 1,724 company-year observations for the period of 2007 to 2018. 


\section{Measurement of Variables and Empirical Models}

\section{Dependent Variable}

We measure the overall ESG performance using the sum of environmental score (ENV), social score (SOC) and governance score (GOV)or ESG score. Each ENV, SOC and GOV score ranges from 0 to 100 , depending on firms' performance on environmental, social, and corporate governance, which are updated annually and are constructed based on approximately 120 quantitative and qualitative measures by the Bloomberg analysts (Bloomberg, 2017). Grewal et al. (2017) indicate that the Bloomberg ESG data is constructed according to the standards developed by the Sustainability Accounting Standards Board (SASB) and therefore represents the most accurate measures of firms' sustainability practices.

The environmental score (ENV) contains data on aspects such as energy use, water consumption and waste generation. The social score (SOC) focuses on elements, such as employee turnover, number of accidents at work and the proportion of woman across the workforce. The governance score (GOV) includes data on aspects such as board structure and characteristics (Bloomberg, 2017; Giannarakis, Konteos, and Sariannidis, 2014). We also examine the impact of board networks on environmental (ENV), Social (SOC) and governance (GOV), performance separately.

\section{Independent Variables}

We follow existing literature (Chuluun et al., 2014; Houston, Lee, and Suntheim, 2018; Larcker et al., 2013; Renneboog and Zhao, 2011) to construct the board network centrality. Each firm is considered as a node in the network and two firms are connected if they share at least one interlocking director. Specifically, the degree centrality (DEG) measures the total number of direct connections to the other firms through interlocking directorates. Firms may be well connected if they have relatively more links than others can influence other firms or 
use their links to access resources. The closeness centrality (CLOSE) measures how close it is to all other firms through the reachable shortest paths. Firms with higher closeness centrality can access resources or information faster than other firms. Unlike degree centrality, closeness is not just a local measure but also based on the distance between a firm to other firms. The eigenvector centrality (EIGEN) measures the quality or the power of the firm within a network. Firms with higher eigenvector centrality may have more power to influence other firms in terms of information dissemination and exchange. The betweenness centrality (BETW) measures how often a firm can sit between two other firms through director interlocks. If a firm sits between many other firms, it may act like a "gatekeeper" and control the flow of information through the network. The information centrality (INFO) captures its direct or indirect connections, not only through the shortest paths but also any other possible indirect paths to other firms that provide verifications on the accuracy of information. Stephenson and Zelen (1989) and Fitch and Leonard (2013) indicate that information centrality represents access to information with the least noise. Hence, firms with higher information centrality can gain more accurate information compared to closeness centrality, which only considers the shortest paths. To account for the lag effect of board networks on firms' ESG performance, we use the oneyear lag of these five measures in our regression models.

\section{Control Variables}

Following prior studies (Horton et al., 2012; Larcker et al., 2013; Money, and Schepers, 2007), we include a number of control variables while examining the relationship between board networks and ESG performance. Board size is the total number of executive and nonexecutive directors. Board independence is the number of independent non-executive directors divided by total number of board members. Tenure measures the number of years the current CEO has served as the CEO of the firm in year t. Age measures the CEO's age. Education 
measures the number of qualifications at undergraduate level and above the current CEO have in year t. Gender is a dummy variable, equals 1 if CEO is female and 0 otherwise. Busy board is a dummy variable, equals 1 if more than half of the directors hold three or more directorships and 0 otherwise. Institutional measures the percentage of shares held by institutional shareholders to total firm ordinary shareholdings. ROA is profit before tax as percentage of total asset. Leverage is the ratio of total debt to total assets. Detailed variable definitions, including dependent variables, independent variables and control variables are reported in the Appendix.

Insert Table 1 about here

\section{Empirical Model}

To test our hypothesis, we use both univariate and multivariate analyses. More specifically, our initial empirical analyses consist of (i) summary statistics; (ii) bivariate analysis conducted by estimating Pearson correlation coefficients; and (iii) pooled ordinary least square is employed as baseline model to conduct multivariate regression analysis and the standard errors are clustered based on firm and year.

Our baseline model to examine the relationship between the impact of board networks and ESG is specified as follows:

$$
E S G_{i t}=\alpha_{0}+\beta_{1} \text { Board_Networks }_{i t-1}+\sum_{i=1}^{n} \gamma_{i} \text { CONTROLS }_{i t}+\delta_{i}+\varepsilon_{i t}
$$

where $E S G$ is our dependent variables ( $E S G, E N V$, SOC, AND GOV), the Board_Networkst t 1 is independent variable which refers to one-year lag of degree centrality, closeness centrality, eigenvector centrality, betweenness centrality and information centrality. CONTROLS refers to a set of control variables, namely, board size (BSIZE), board independence (BINDEP), CEO 
tenure, age, education, gender (TENURE, AGE, EDUC, WCEO), busy board (BBOARD), institutional ownership (INSTIT), return on assets (ROA), and financial leverage (LEV).

Insert Panel A of Table 1 about here

\section{Summary Statistics and Regression Results}

Descriptive Statistics

Table 1 presents the summary statistics for our sample. The average firms' ESG scores is 36 while the averages of ESG components: environmental (ENV), social (SOC), and governance (GOV)scores are 25.42, 38.73 and 57.66 respectively. The averages of degree centrality (DEG), closeness centrality (CLOSE), eigenvector centrality (EIGEN), betweeness centrality (BETW), and information centrality (INFO) (stated in \%) are 1.3, 13.1, 4.3, 1.21, and 3.99 respectively. The average board size (BSIZE) in our sample is 9.03 and $61.01 \%$ directors are considered as independent (non-executives) directors (BINDEP). On average, CEO's tenure is 6.3 years (TENURE) and the average CEO's age is 54.15 years old (AGE). On average, CEOs hold two qualifications (EDUC). Approximately, 27\% of the firms have more than a half of their boards with three or more directorships (BBOARD) and 5\% of the CEOs are female (WCEO). These averages are similar with existing studies (e.g., Renneboog and Zhao, 2011). On average, $11.33 \%$ of the firms' shares in our sample are held by institutional investors (INSTIT). The average return on assets (ROA) and total debt-to-asset ratio (LEV) of our sample firms are $6.73 \%$ and $23.97 \%$. On average, the firms in our sample has $26 \%$ industry concentration (HHI), which is consistent with Powell and Yawson (2005) that use the UK sample firms. Approximately, 3.5\% of the board seats are held by women (WBOD). 
Panel B of Table 1 displays the distribution of our sample across nine different sectors. We find that firms' ESG measures vary across different sectors. More importantly, we find that board networks measures are positively related to industry concentration (HHI) and the percentage of women boards (WBOD), which implies firms that operate in more concentrated industry and firms with higher percentage of women boards tend to have higher board networks.

Insert Table 2 about here

Table 2 presents the Pearson correlations between our dependent variables (ESG measures), board networks and control variables. Consistent with our hypothesis, we find that ESG measures are positively and significantly correlated with the board networks measures. We find that five board networks measures (DEG, EIGEN, CLOSE, BETW, INFO) are positively and highly correlated to one another. Therefore, we cannot include all five networks measures in the same regression equation due to a multicollinearity problem among five different board networks measures. We also find that the board size (BSIZE) and the percentage of independent boards (BINDEP) are also positively correlated with board network measures. We find that the correlations between the board network measures and control variables are less than 0.4. The correlations among control variables are generally less than 0.4 , except for the percentage of independent board (BINDEP) and the percentage of women board (WBOD). Thus, we would not expect any serious multicollinearity problems in our multivariate regressions. 


\section{Regression Results}

We examine the relationship between board networks and firms' overall ESG performance. Table 3 presents the linear regression results between various measures of board networks and firms' ESG performance. We find that all of our five measures of board networks are positively related to firms' ESG performance. We find that one percent increase in boards' degree of centrality (DEG), board network closeness (CLOSE), and quality (EIGEN) increase the ESG score by $0.631,0.237$ and 0.04 respectively. One percent increase in board betweenness (BETW) and information network (INFO) increases the firms' ESG score by 0.311 and 0.115 respectively. These findings indicate that board networks are positively associated with ESG performance. Thus, we find empirical evidence to support our hypothesis that having boards with richer networks, measured by the total number of connections to other firms, shortest distance to other firms, the rank of importance from direct and indirect links, gatekeeper and control of information flow, and access to information with the least noise, can facilitate the firms' ability to better manage and meet the needs of multiple stakeholders (stakeholder management).

Second, we separately examine the relations between board networks with each of the three components of firms' overall ESG: environment (ENV), social (SOC), and governance (GOV) scores. Table 3 shows that the relationship between board networks measures and firms' environment (ENV), social (SOC), and governance (GOV) scores are generally positive and significant, except for information centrality (INFO) and social performance (SOC). Overall results from examining the components of ESG support our hypothesis that greater board networks is positively related with better environmental (ENV), social (SOC) and governance 
(GOV) performance. We also use the two-year lag of board networks and the unreported results are consistent with our reported results.

Insert Table 4 about here

Extant literature has found that there is a non-linear relationship between board characteristics and firm performance (Coles, Daniel and Naveen, 2008; Chang et al., 2015). Therefore, we further explore whether there is a non-linear (curvilinear) relationship between board networks and firms' ESG performance. We regress the quadratic function of board networks (e.g., $\mathrm{DEG}_{\mathrm{t}-1}$ and $\mathrm{DEG}_{\mathrm{t}-1}{ }^{2}$ ) on firms' ESG and the results are presented in Table 4. We find that the coefficients of board networks remain positive and statistically significant. However, we find that the coefficients of the squared of board networks are negative and statistically significant. Thus, the relationship between board networks and firms' ESG performance is concave (non-linear), indicating there is a diminishing return of board networks on firms' ESG performance.

\section{Additional Analysis}

Recent studies have shown that there is a relationship between board diversity and board networks. Booth-Bell (2018) argues that more diverse boards tend to bring more diverse social capital that bridge the boards' networks and their tasks to advice, counsel, and monitor. Thus, board diversity enhances firms' corporate governance through their indirect link of boards' diverse networks. Ooi, Hooy, and Som (2017) also demonstrates that board diversity in human and social capital network ties significantly mitigates the negative effects of crises. Goyal (2017) and Basuony, Mohamed, and Samaha (2018) examine the positive impacts of 
board diversity in the UK firms and find that board gender diversity influence the effectiveness of the board. Kim and Starks (2016) also document that women boards provide additional advisory skills and expertise such as risk management, sustainability and regulatory compliance. They argue that greater heterogeneity of expertise that women directors bring into the boardrooms come from their social networks that are significantly different from men. Based on existing literature, we conduct further empirical investigation whether board gender diversity influence the firms' board networks.

Insert Panel A of Table 5 about here

Furthermore, based on our descriptive statistics presented in Panel B of Table 1 indicates that firms that operate in more concentrated sectors (higher HHI) tend to have higher board networks. Therefore, we also examine whether the market concentration, measured by HHI, influence board networks. Essentially, our additional analysis here is to account for potential endogeneity issue of board networks. Thus, we conduct the two-stage regression (2SLS) analyses where in the first stage regression, we examine the impacts of board gender diversity and industry concentration on the board networks. In the second stage regression, we examine the impact of board networks on firms' ESG performance.

Insert Panels B and C of Table 5 about here

The results of the 2SLS regressions are presented in Table 5. The first stage regression results presented in panel A of Table 5 indicate that board gender diversity (WBOD) and 
industry concentration (HHI) positively affect board networks. Thus, we find evidence that greater board gender diversity and firms that operate in sectors that are more concentrated tend to have higher board networks. The second stage regression results presented in both panel B (linear) and panel C (quadratic) are qualitatively similar to our baseline results presented in Tables 3 and 4 respectively, indicating our findings remain robust even after controlling for a potential endogeneity issue

\section{Conclusions}

Recent global financial crisis has made corporate social responsibility performance to become an increasingly critical aspect of firms' business strategic and stakeholder management. Firms are continuously receiving pressures from their stakeholders and must strategically address their environmental, social, and governance (ESG) concerns in order to manage the pressures from various stakeholders. Therefore, this study examines the monitoring and advising roles of board of directors and investigates the impact of board networks on firms' ESG performance.

Our findings indicate that having boards with greater social capital, measured by the board networks, is positively related with greater ESG performance. Our finding is consistent with the stakeholder theory (Donaldson and Preston, 1995) by identifying the connection between stakeholder management and the traditional corporate objectives to gain competitive advantage through having boards with higher networks. Furthermore, we find that board gender diversity and the industry characteristic, measured by the industry concentration, are positively related to board networks. Therefore, board networks are endogenously determined by board diversity and the industry concentration.

We also find a diminishing return on board networks on subsequent ESG performance indicating that a continuing increase in board networks does not always lead to higher ESG 
performance in the subsequent period. Thus, we believe that our diminishing return of board networks on ESG performance result is also consistent with existing literature which indicate that there are potential downsides of having greater board networks that have been identified in the literature, such as the groupthink and less effective monitoring (Benabou, 2012; Coles, Daniels, and Naveen, 2015), lack of innovations (Aronson, Reilly and Lynn, 2019), and greater conflict of interests (Scharff, 2005).

Overall, our study extends the extant studies that examine the importance of board networks on firms' decision-making (Carpenter and Westphal, 2001; Thorgren, et al., 2010) and the relationship between board networks and firms' financial performance (Chahine and Goergen, 2013; Chuluun et al., 2014; Horton et al., 2012; Larcker et al., 2013). As illustrated in Figure 1, our study also extends the social capital (Adler and Kwon, 2002), the social network theory of stakeholder influence (Rowley, 1997; Neville and Menguc, 2006), and the stakeholder management (Freeman, 1984; Donaldson and Preston, 1995) by establishing the interconnections among these theories.

While our study is based on a sample of UK listed firms, future studies can extend our study by examining the nexus of board networks and ESG performance in different international environments, such as the emerging markets (Singh and Delios, 2017). Given the diminishing return of board networks on firms' ESG performance, we believe that future research could also examine whether and how increasing networks may lead to unethical behaviour (i.e., insider trading). Finally, although the results of this study are robust to alternative estimations, our study has some limitations including limiting the analysis only to the network of the firms' networks through their board of directors. Future studies can consider also examine the firms' social networks from outside of the firms such as industry alliance and joint ventures (Macaulay et al., 2018). 


\section{References}

Adler, P. S. and Kwon, S. W. (2002). 'Social capital: Prospects for a new concept', Academy of Management Review, Vol. 27 No. 1, pp. 17-40.

Aguilera, R. V. (2005). 'Corporate governance and director accountability: An institutional comparative perspective', British Journal of Management, Vol. 16 No. 81, pp. 1-15.

Aguilera, R.V., Williams, C. A., Conley J. M. and Rupp, D. E. (2006). 'Corporate governance and social responsibility: A comparative analysis of the UK and US firms', Corporate Governance: An International Review, Vol. 14 No. 3, pp. 147-158.

Ahuja, G. (2000). 'Collaboration networks, structural holes, and innovation: a longitudinal study’, Administrative Science Quarterly, Vol. 45 No. 3, pp. 425-455.

Alipour, M., Ghanbari, M., Jamshidinavid, B. and Taherabadi, A. (2019). 'Does board independence moderate the relationship between environmental disclosure quality and performance? Evidence from static and dynamic panel data', Corporate Governance: The International Journal of Business in Society, Vol. 19. No. 3, pp. 580-610.

Aronson, Z. H., Reilly, R. R. and Lynn, G. S. (2019). 'Understanding the role of team member personal style in project performance: Does the type of innovation matter?', International Journal of Innovation and Technology Management, Vol. 16 No. 4, pp. $1-37$.

Bainbridge, S. M. (2017). 'Corporate directors in the United Kingdom', Williams \& Mary Law Review Online, Vol. 59, pp. 65-84.

Baker, W. (1990). 'Market networks and corporate behavior', American Journal of Sociology, Vol. 96 No. 3, pp. 589-625.

Basuony, M. A. K., Mohamed, E. K. A. and Samaha, K. (2017). 'Board structure and corporate disclosure via social media: an empirical study in the UK', Online Information Review, Vol. 42 No. 5, pp. 595-614.

Benabou, R. (2012). 'Groupthink: collective delusions in organizations and markets', Review of Economic Studies, Vol. 80. No. 2, pp. 429-462.

Bloomberg. (2017). 'Sustainability is embedded in our products, operations and people', Bloomberg Impact Report. Available at https://data.bloomberglp.com/company/sites/39/2018/07/Bloomberg-SustainabilityImpact-Report-2017-Web-3.pdf

Booth-Bell, D. (2017). 'Social capital as a new board diversity rationale for enhanced corporate governance', Corporate Governance: The International Journal of Business in Society, Vol. 18 No. 3, pp. 425-439.

Bourdieu, P. (1972). Outline of a Theory of Practice. Cambridge University Press, Cambridge, UK. 
Bourdieu, P. (1985). 'The forms of capital'. In J. G. Richardson (Ed.), Handbook of Theory and Research for the Sociology of Education, pp. 241-258. New York: Greenwood.

Brammer, S., Jackson, G. and Matten, D. (2012). 'Corporate social responsibility and institutional theory: New perspective on new governance', Socio Economic Review, Vol. 10 No. 22, pp. 3-28.

Burt, R. S. (1987). 'Social contagion and innovation: Cohesion versus structural equivalence’, American Journal of Sociology, Vol. 92 No. 6, pp. 1287-1335.

Burt, R. S. (1992). Structural Holes: The Social structure of Competition. Harvard University Press: Cambridge, MA.

Burt, R. S. (1997). 'The contingent value of social capital', Administrative Science Quarterly, Vol. 42 No. 2, pp. 339-365.

Burt, R. S. (2000). 'The network structure of social capital', Research in Organizational Behavior, Vol. 22, pp. 345-423.

Carpenter, M. A. and Westphal, J. D. (2001). 'The strategic context of external network ties: Examining the impact of director appointments on board involvement in strategic decision making', Academy of Management Journal, Vol. 4 No. 4, pp. 639-660.

Chahine, S. and Goergen, M. (2013). 'The effects of management-board ties on IPO performance', Journal of Corporate Finance, Vol. 21 No. 1, 153-179.

Chang, Y. K., Oh., W., Park, J H. and Jang, M. G. (2015). 'Exploring the Relationship Between Board Characteristics and CSR: Empirical Evidence from Korea', Journal of Business Ethics, Vol. 140. No. 2, pp. 225-242.

Chuluun, T., A. Prevost and J. Puthenpurackal (2014). 'Board ties and the cost of corporate debt', Financial Management, 43(3), pp. 533-568.

Cohen, L., Frazzini, A. and Malloy, C. (2008). 'The small world of investing: board connections and mutual fund returns', Journal of Political Economy, Vol. 116 No. 5, pp. 951-979.

Cohen, L., Frazzini, A. and Malloy, C. (2010). 'Sell-side school ties', Journal of Finance, Vol. 65 No. 4, pp. 1409-1437.

Coles, J. L., Daniel, D. N., \& Naveen, L. (2008). 'Boards: Does one size fit all?', Journal of Financial Economics, Vol. 87 No. 2, pp. 329-356.

Coles, J. L., Daniel, D. N., \& Naveen, L. (2015). 'Director overlap: Groupthink versus teamwork', University of Utah Working Paper.

Collins, C. J. and Clark, K. D. (2003). 'Strategic human resource practices, top management team social networks, and firm performance: The role of human resource practices in creating organizational competitive advantage', Academy of Management Journal, Vol. 46 No. 6, pp. 740-751. 
Conyon, M. J. and Muldoon, M. R. (2006). 'The small world of corporate boards', Journal of Business Finance and Accounting, Vol. 33 No. 9-10, pp. 1321-1343.

Conyon, M. J. and Peck, S. I. (1998). 'Board control, remuneration committees, and top management compensation', Academy of Management Journal, Vol. 41 No. 2, pp. 146-157.

Donaldson, T. and Preston, L. E. (1995). 'The stakeholder theory of the corporation: Concepts, evidence, and implications', Academy of Management Review, Vol. 20 No. 1, pp. 65-91.

Elmagrhi, M. H., Ntim, C. G. and Wang, Y. (2016). 'Antecedents of voluntary corporate governance disclosure: a post-2007/08 financial crisis evidence from the influential UK Combined Code', Corporate Governance: The International Journal of Business in Society, Vol. 13 No. 3, pp. 507-537.

Fitch, K. and Leonard, N. E. (2013). 'Information centrality and optimal leader selection in noisy networks', Proceedings of the $52^{\text {nd }}$ IEEE Conference in Decision and Control. https://doi.org/10.1109/CDC.2013.6761082.

Foa, U. G. and Foa, E. B. (1974). Societal structures of the mind. Springfield, IL: Charles C. Thomas.

Foa, U. G. and Foa, E. B. (1980). 'Resource theory: Interpersonal behavior as exchange'. In K. J. Gergen and M. S. Greenberg and R. H. Willis (Eds.), Social exchange: Advances in theory and research. New York: Plenum.

Forbes, D. P. and Milliken, F. J. (1999). 'Cognition and corporate governance: Understanding boards of directors as strategic decision-making groups', Academy of Management Review, Vol. 24 No. 3, pp. 489-505.

Freeman, R. E. (1984). Strategic Management: A Stakeholder Approach. Cambridge, UK: Cambridge University Press.

Giannarakis, G., Konteos, G. and Sariannidis, N. (2014). 'Financial, governance and environmental determinants of corporate social responsible disclosure', Management Decision, Vol. 52 No. 10, pp. 1928-1951.

Grewal, J., Hauptmann, C. and Serafeim, G. (2017). 'Material sustainability information and stock price informativeness', Harvard Business School Working Paper. Available at https://papers.ssrn.com/sol3/papers.cfm?abstract_id=2966144

Godfrey, P. C. (2005). 'The relationship between corporate philanthropy and shareholder wealth: A risk management perspective', Academy of Management Review, Vol. 30 No. 4, pp. 777-798.

Godfrey, P. C., Merrill, C. B. and Hansen, J. M. (2009). 'The relationship between corporate social responsibility and shareholder value: An empirical test of risk management hypothesis', Strategic Management Journal, Vol. 30 No. 4, pp. 425-445. 
Goergen, M., Chahine, S., Wood, G. and Brewster, C. (2019). 'The relationship between public listing, context, multi-nationality and internal CSR', Journal of Corporate Finance, Vol. 57, pg. 122-141.

Goyal, R. (2019). 'Improving corporate governance with functional diversity on FTSE 350 boards: directors' perspective', Journal of Capital Markets Studies, Vol. 3 No. 2, pp. 113-116.

Harjoto, M. A., Laksmana, I. and Yang Y. (2019). 'Board nationality and educational background diversity and corporate social performance', Corporate Governance: The International Journal of Business in Society. Vol. 19. No. 2, 217-239.

Hillenbrand, C., Money, K. and Ghobadian, A. (2013). 'Unpacking the mechanism by which corporate responsibility impacts stakeholder relationships', British Journal of Management, Vol. 24 No. 1, pp. 127-146.

Hochberg, Y., Ljungqvist, A. and Lu, Y. (2007). 'Whom you know matters: venture capital networks and investment performance', Journal of Finance, Vol. 62 No. 1, pp. 251301.

Hopt, K. J. and Leyens, P. (2004). 'Board models in Europe - Recent developments of internal corporate governance structures in Germany, the United Kingdom, France, and Italy', European Company and Financial Law Review, Vol. 1 No. 2, pp. 135-168.

Horton, J., Millo, Y. and Serafeim, G. (2012). 'Resources or power? Implications of Social Networks on compensation and firm performance', Journal of Business Finance and Accounting, Vol. 39 No. 3-4, pp. 399-426.

Houston, J. F., Lee, J. and Suntheim, F. (2018). 'Social networks in the global banking sector’, Journal of Accounting and Economics, Vol. 65 No. 2-3, pp. 237-269.

Inkpen, A. C. and Tsang, E. W. K. (2005). 'Social capital, networks, and knowledge transfer', Academy of Management Journal, Vol. 30 No. 1, pp. 146-165.

Jacobs, J. (1961). The Death and Life of Great American Cities. Random House, New York.

Jang, S. S., Ko, H., Chung, Y. and Woo, C. (2019). 'CSR, social ties and firm performance', Corporate Governance: The International Journal of Business in Society. Vol. 19 No. 6, pp. 1310-1323.

Kacanski, S. (2019). 'Structure behind principles: social selection mechanisms in corporate governance networks', Corporate Governance: The International Journal of Business in Society, Vol. 20 No. 1, pp. 87-105.

Kim, D. and Starks, L. T. (2016). 'Gender diversity on corporate boards: Do women contribute unique skills?', American Economic Review: Papers \& Proceedings, Vol. 106 No. 5, pp. 267-271. 
Kinderman, D. (2012). 'Free us up so we can be responsible! The co-evolution of corporate social responsibility and neo-liberalism in the UK, 1977-2010', Socio-Economic Review, Vol. 10 No. 1, pp. 29-57.

Koka, B. R. and J. E. Prescott, J. E (2002). 'Strategic alliances as social capital: A multidimensional view’, Strategic Management Journal, Vol. 23 No. 9, pp. 795-816.

Krenn, M. (2017). 'Competing institutional pressures in corporate governance reform: the role of board interlocks and industry peers', : The International Journal of Business in Society, Vol. 17 No. 3, pp. 538-559.

Kuhnen, C. (2009). 'Business networks, corporate governance and contracting in the mutual fund industry', Journal of Finance, Vol. 64 No. 5, pp. 2185-2220.

Larcker, D. F., So, E. C. and Wang, C. C. Y. (2013). 'Board centrality and firm performance', Journal of Accounting and Economics, Vol. 55 No. 2-3, pp. 225-250.

Letki, N. 2008. 'Does diversity erode social cohesion? Social capital and race in British neighbourhoods', Political Studies, Vol. 56 No. 1, pp. 99-126.

Macaulay, C. D., Richard, O.C., Peng, M. W. and Hassenhuttl, M. (2018). 'Alliance network centrality, board composition, and corporate social performance', Journal of Business Ethics, Vol. 151 No. 4, pp. 997-1008.

Money, K. and Schepers, H. (2007). 'Are CSR and corporate governance converging? A view from boardroom directors and company secretaries in FTSE100 companies in the UK', Journal of General Management, Vol. 33 No. 2, pp. 1-11.

Muthuri, J. N., Matten, D. and Moon, J. (2009). 'Employee volunteering and social capital: Contributions to corporate social responsibility', British Journal of Management, Vol. 20 No. 1, pp. 75-89.

Nahapiet, J. and Ghoshal, S. (1998). 'Social capital, intellectual capital, and the organizational advantage', Academy of Management Review, Vol. 23 No 2, pp. 242266.

Neville, B.A. and Menguc, B. (2006). 'Stakeholder multiplicity: Toward an understanding of the interactions between stakeholders', Journal of Business Ethics, Vol. 66 No. 4, pp. 377-391.

Oh, H., Chung, M. H. and Labianca, G. (2004). 'Group social capital and group effectiveness: The role of informal socializing ties', Academy of Management Journal, Vol. 47 No. 6, pp. 860-875.

Ooi, C., Hooy, C. and Som, A. P. M. (2017). 'The influence of board diversity in human capital and social capital in crisis', Managerial Finance, Vol. 43. No. 6, pp. 700-719.

Pichler, F. and Wallace, C. (2007). 'Patterns of formal and informal social capital in Europe', European Sociological Review, Vol. 23 No. 4, pp. 423-435. 
Powell, R. and Yawson, A. (2005). 'Industry aspects of takeovers and divestitures: Evidence from the UK', Journal of Banking and Finance, Vol. 29. No. 12, pp. 3015-3040.

Renneboog, L., and Zhao, Y. (2011). 'Us know us in the UK: On director networks and CEO compensation', Journal of Corporate Finance, Vol. 17 No. 4, pp. 1132-1157.

Rowley, T.J. (1997). 'Moving beyond dyadic ties: A network theory of stakeholder influences', Academy of Management Review, Vol. 22 No. 4, pp. 887-910.

Scharff, M. M. (2005). 'Understanding WorldCom's Accounting Fraud: Did Groupthink Play a Role?', Journal of Leadership and Organizational Studies, Vol. 11 No. 3, pp. 109118.

Seibert, S. E., Kraimer, M. L. and Liden, R. C. (2001). 'A social capital theory of career success', Academy of Management Journal, Vol. 44 No. 2, pp. 219-237.

Seidel, M., Polzer, J. and Stewart, K. (2000). 'Friends in high places: the effects of social networks on discrimination in salary negotiations', Administrative Science Quarterly, Vol. 45 No. 1, pp. 1-24.

Singh,D. and Delios, A. (2017). 'Corporate governance, board networks and growth in domestic and international markets: Evidence from India', Journal of World Business, Vol. 52 No. 2, 615-627.

Sparrowe, R. T., Liden, R. C., Wayne, S. J. and Kraimer, M. L. (2001). 'Social networks and the performance of individuals and groups', Academy of Management Journal, Vol. 44 No. 2, pp. 316-325.

Stephenson, K. A. and Zelen, M. (1989). 'Rethinking centrality: Methods and examples', Social Networks, Vol. 11 No. 1, pp. 1-37.

Swanson, D. L. and Orlitzky, M. (2018). 'Leading the triple bottom line a corporate social responsibility approach'. In Ones, D. S., Anderson, N., Viswesvaran, C. and Sinagil, H. K. (Eds.), $2^{\text {nd }}$ edition. The SAGE Handbook of Industrial, Work, and Organizational Psychology, Vol. 3. Sage, Thousand Oaks, CA, pp. 313-332.

Thorgren, S., Wincent, J. and Anokhin, S. (2010). 'The importance of compensating strategic network board members for network performance: A contingency approach'. British Journal of Management, Vol. 21 No. 1, pp. 131-151.

Tsai, W. and Ghoshal, S. (1998). 'Social capital and value creation: the role of intrafirm networks’, Academy of Management Journal, Vol. 41 No. 4, pp. 464-476.

United Nations Global Compact. (2017). 2017 United Nations Global Compact Progress Report: Business Solutions to Sustainable Development. Available at https://www.unglobalcompact.org/library/5431

Useem, M. (1984). The inner circle: Large corporations and the rise of business political activity in the US and UK. Oxford University Press, New York. 
Van Veen, K. and Elbertsen, J. (2008). 'Governance regimes and nationality diversity in corporate boards: A comparative study of Germany, the Netherlands, and the United Kingdom', Corporate Governance: An International Review, Vol. 16 No. 5, pp. 386399.

Vo, L. V., Le, T. T. H. and Kim, Y. (2020). 'Board network centrality and corporate social responsibility'. Working Paper. Available at https://papers.ssrn.com/sol3/papers.cfm?abstract_id=3453776.

Wang, Y., Abbasi, K., Babajide, B. and Yekini, K. (2019). 'Corporate governance mechanisms and firm performance: evidence from the emerging market following the revised CG code', Corporate Governance: The International Journal of Business in Society, Vol. 20 No.1, pp. 158-174.

Woolcock, M. (1998). 'Social capital and economic development: Toward a theoretical synthesis and policy framework', Theory and Society, Vol. 27 No. 2, pp. 151-208.

Woolcock, M. and D. Narayan (2000). 'Social capital: Implications for development theory, research and policy', World Bank Research Observer, Vol. 15 No. 1, pp. 225-250.

Zaheer, A. and G. G. Bell (2005). 'Benefiting from network position: firm capabilities, structural holes, and performance', Strategic Management Journal, Vol. 26 No. 9, pp. 809-825. 


\section{APPENDIX}

\section{Definitions of Variables}

\begin{tabular}{|c|c|}
\hline \multicolumn{2}{|c|}{ Panel A: Dependent Variables (ESG) } \\
\hline $\mathrm{ESG}_{\mathrm{t}-1}$ & $\begin{array}{l}\text { One-year lag of environmental, social, and corporate governance score. It represents } \\
\text { the firms' overall ESG score }=\mathrm{ENV}+\mathrm{SOC}+\mathrm{GOV}\end{array}$ \\
\hline $\mathrm{ENV}_{\mathrm{t}-1}$ & $\begin{array}{l}\text { One-year lag of environmental measures a company's impact on living and non- } \\
\text { living natural systems, including the air, land and water, as well as complete } \\
\text { ecosystems. It reflects how well a company uses best management practices to avoid } \\
\text { environmental risks and capitalize on environmental opportunities in order to } \\
\text { generate long-term shareholder value. }\end{array}$ \\
\hline $\mathrm{SOC}_{\mathrm{t}-1}$ & $\begin{array}{l}\text { One-year lag of social measures a company's capacity to generate trust and loyalty } \\
\text { with its workforce, customers and society, through its use of best management } \\
\text { practices. It is a reflection of the company's reputation and the health of its license } \\
\text { to operate, which are key factors in determining its ability to generate long term } \\
\text { shareholder value. }\end{array}$ \\
\hline $\mathrm{GOV}_{\mathrm{t}-1}$ & $\begin{array}{l}\text { One-year lag of corporate governance measures a company's systems and processes, } \\
\text { which ensure that its board members and executives act in the best interests of its } \\
\text { long-term shareholders. It reflects a company's capacity, through its use of best } \\
\text { management practices, to direct and control its rights and responsibilities through } \\
\text { the creation of incentives, as well as checks and balances in order to generate long- } \\
\text { term shareholder value. }\end{array}$ \\
\hline
\end{tabular}

Panel B: Independent Variables (Board Networks)

DEG The normalized degree centrality of a firm is the number of other firms it connects to through director interlocks (in \%).

CLOSE The normalized closeness centrality of a firm measures how close (shortest path) it is to all the other reachable firms (in \%).

EIGEN The eigenvector centrality of a firm measures, not only the number of other firms it connects to, but also the quality of the other firms it connects to (in \%).

BETW The normalized betweenness centrality of a firm measures how often a firm can sit between two other firms through director interlocks (in \%).

INFO The information centrality of a firm captures its direct or indirect connections, not only through the shortest paths but also any other possible paths to other firms with the least noise (in \%).

\section{Panel C: Control Variables}

BSIZE The total number of executive and non-executive directors.

BINDEP Number of independent non-executive directors divided by total number of board members

TENURE The number of years the current CEO has served as the CEO of the firm in year $\mathrm{t}$.

AGE CEO's age in year $t$.

EDUC The number of qualifications at undergraduate level and above that current CEO has in year $\mathrm{t}$.

WCEO Dummy variable, 1 if CEO is female and 0 otherwise.

BBOARD Dummy variable, 1 if more than half of the directors hold three or more directorships and 0 otherwise.

INSTIT Percentage of shares held by institutional shareholders to total firm ordinary Shareholdings.

ROA Profit before tax as percentage of total asset.

LEV Ratio of total debt to total assets.

HHI Industry concentration, measured by the Herfindahl index of firms' net revenue in each year across nine sectors based on the GICS classification

WBOD Percentage of women board (board diversity) 


\section{Figure 1}

Social Capital, Social Network of Stakeholder Influence, Stakeholder Management, and ESG Performance

Social Capital

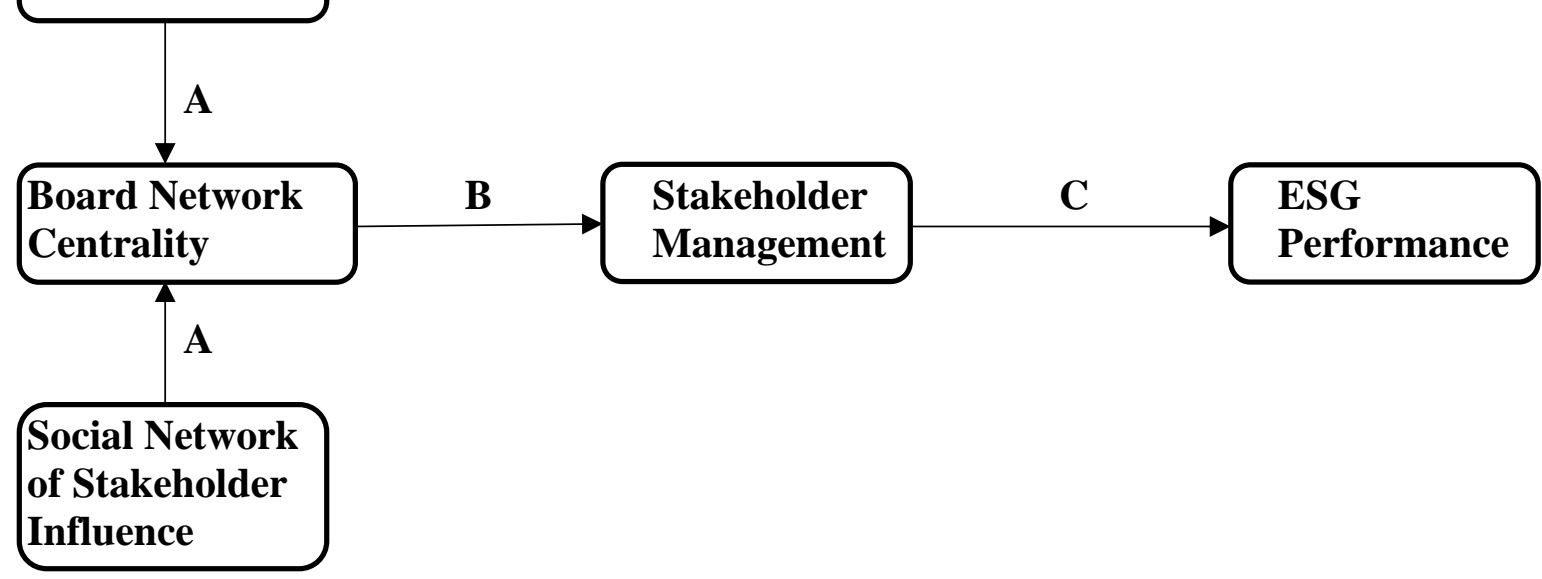

Figure 1 displays the interconnections among social capital, social networks of stakeholder influence, stakeholder management, and ESG performance 
TABLE 1

Descriptive Statistics

Panel A. Summary Statistics

\begin{tabular}{lcccccccc}
\hline Variable & Obs & Mean & Std. Dev. & Min & 25pctile & Median & 75 ptile & Max \\
\hline ESG & 1724 & 36.00 & 11.10 & 11.11 & 28.10 & 34.30 & 42.15 & 70.12 \\
ENV & 1724 & 25.42 & 13.98 & 1.55 & 15.50 & 22.48 & 34.11 & 68.60 \\
SOC & 1724 & 38.73 & 12.91 & 11.11 & 28.07 & 38.60 & 45.61 & 89.47 \\
GOV & 1724 & 57.66 & 7.06 & 41.07 & 53.57 & 57.14 & 62.5 & 82.14 \\
DEG $_{\text {t- }}$ & 1724 & 1.30 & 0.98 & 0 & 0.5 & 1.1 & 2 & 5.7 \\
CLOSE $_{\mathrm{t}-1}$ & 1724 & 13.10 & 3.41 & 6.3 & 10.83 & 13.8 & 15.7 & 20.2 \\
EIGEN $_{\mathrm{t}-1}$ & 1724 & 4.30 & 5.84 & 0 & 0.13 & 2.1 & 6 & 42.9 \\
BETW $_{\mathrm{t}-1}$ & 1724 & 1.21 & 1.71 & 0 & 0 & 0.5 & 1.9 & 11.6 \\
INFO $_{\mathrm{t}-1}$ & 1724 & 3.99 & 1.62 & 0.8 & 4 & 4.6 & 5.2 & 5.8 \\
BSIZE & 1724 & 9.03 & 2.13 & 4 & 8 & 9 & 10 & 19 \\
BINDEP & 1724 & 61.01 & 12.79 & 0 & 50 & 62.5 & 71.43 & 92.86 \\
TENUR & 1724 & 6.30 & 5.94 & 0.08 & 2.17 & 4.75 & 8.5 & 41.5 \\
AGE & 1724 & 54.15 & 5.50 & 35 & 51 & 54 & 57 & 77 \\
EDUC & 1724 & 1.86 & 1.10 & 0 & 1 & 2 & 3 & 6 \\
WCEO & 1724 & 0.05 & 0.22 & 0 & 0 & 0 & 0 & 1 \\
BBOARD & 1724 & 26.65 & 29.24 & 0 & 0 & 25 & 50 & 100 \\
INSTIT & 1724 & 11.33 & 3.34 & 0 & 9.63 & 11.27 & 12.66 & 46.06 \\
ROA & 1724 & 6.73 & 9.01 & -68.95 & 3.06 & 6.07 & 10.34 & 70.25 \\
LEV & 1724 & 23.97 & 17.39 & 0 & 10.67 & 22.79 & 34.04 & 89.16 \\
HHI & 1724 & 0.26 & 0.06 & 0.12 & 0.22 & 0.25 & 0.31 & 0.52 \\
WBOD & 1724 & 3.49 & 2.44 & 0 & 2.08 & 3.16 & 5.27 & 12 \\
\hline
\end{tabular}

Panel B. Descriptive Statistics across nine GICS sectors

\begin{tabular}{lcccccccccccc}
\hline Sector & Obs. & ESG & ENV & SOC & GOV & DEG & CLOSE & EIGEN & BETW & INFO & HHI & WBOD \\
\hline Energy & 92 & 41.76 & 31.53 & 46.26 & 60.60 & 0.98 & 12.02 & 2.40 & 0.74 & 3.69 & 0.24 & 3.68 \\
Materials & 231 & 42.40 & 32.86 & 45.09 & 61.63 & 1.30 & 12.42 & 3.69 & 1.27 & 3.71 & 0.25 & 2.64 \\
Industrials & 492 & 43.62 & 33.24 & 50.78 & 60.22 & 1.80 & 15.02 & 6.62 & 2.10 & 4.78 & 0.25 & 3.23 \\
Con. Discr. & 362 & 37.65 & 28.18 & 41.02 & 58.27 & 1.09 & 12.48 & 3.50 & 0.92 & 3.71 & 0.23 & 3.68 \\
Con. Stap. & 212 & 35.75 & 26.22 & 35.43 & 57.83 & 1.48 & 14.03 & 5.72 & 1.44 & 4.44 & 0.30 & 2.84 \\
Healthcare & 81 & 34.53 & 24.26 & 35.23 & 55.68 & 0.96 & 12.59 & 2.66 & 0.56 & 3.69 & 0.28 & 3.03 \\
Info Tech & 55 & 23.85 & 11.16 & 28.48 & 53.21 & 0.96 & 12.10 & 3.58 & 0.82 & 3.33 & 0.28 & 2.96 \\
Communic. & 138 & 37.27 & 26.63 & 39.70 & 59.23 & 1.06 & 12.66 & 3.81 & 0.73 & 3.73 & 0.25 & 3.84 \\
Utilities & 61 & 32.91 & 21.11 & 37.34 & 56.29 & 1.52 & 13.76 & 5.12 & 1.55 & 4.30 & 0.27 & 2.53 \\
\hline
\end{tabular}

See Appendix for variables definitions. 
TABLE 2

Pearson Correlations

\begin{tabular}{|c|c|c|c|c|c|c|c|c|c|c|c|}
\hline No & Variables & 1 & 2 & 3 & 4 & 5 & 6 & 7 & 8 & 9 & 10 \\
\hline 1 & ESG & 1 & & & & & & & & & \\
\hline 2 & ENV & $0.955^{*}$ & 1 & & & & & & & & \\
\hline 3 & SOC & $0.809^{*}$ & $0.653^{*}$ & 1 & & & & & & & \\
\hline 4 & GOV & $0.761^{*}$ & $0.669 *$ & $0.556^{*}$ & 1 & & & & & & \\
\hline 5 & $\mathrm{DEG}_{\mathrm{t}-1}$ & $0.199^{*}$ & $0.179 *$ & $0.154 *$ & $0.190^{*}$ & 1 & & & & & \\
\hline 6 & CLOSE $_{\mathrm{t}-1}$ & $0.266^{*}$ & $0.225^{*}$ & $0.261 *$ & $0.211^{*}$ & $0.705^{*}$ & 1 & & & & \\
\hline 7 & EIGEN $_{\mathrm{t}-1}$ & $0.107^{*}$ & $0.094 *$ & $0.076^{*}$ & $0.116^{*}$ & $0.763^{*}$ & $0.556^{*}$ & 1 & & & \\
\hline 8 & BETW $_{t-1}$ & $0.156^{*}$ & $0.137 *$ & $0.131 *$ & $0.155^{*}$ & $0.821^{*}$ & $0.503 *$ & $0.702 *$ & 1 & & \\
\hline 9 & $\mathrm{INFO}_{\mathrm{t}-1}$ & $0.239^{*}$ & $0.207 *$ & $0.219^{*}$ & $0.198^{*}$ & $0.635^{*}$ & $0.879^{*}$ & $0.421^{*}$ & $0.392 *$ & 1 & \\
\hline 10 & BSIZE & $0.396^{*}$ & $0.364 *$ & $0.301 *$ & $0.399^{*}$ & $0.151^{*}$ & $0.162 *$ & $0.104 *$ & $0.157^{*}$ & $0.178^{*}$ & 1 \\
\hline 11 & BINDEP & $0.357^{*}$ & $0.3366^{*}$ & $0.331 *$ & $0.249 *$ & $0.289^{*}$ & $0.404 *$ & $0.206^{*}$ & $0.183^{*}$ & $0.331 *$ & $0.157 *$ \\
\hline 12 & TENUR & $-0.099 *$ & $-0.095 *$ & -0.057 & $-0.092 *$ & $-0.147 *$ & $-0.142 *$ & $-0.092 *$ & $-0.123 *$ & $-0.154 *$ & -0.005 \\
\hline 13 & AGE & $0.105^{*}$ & $0.094 *$ & $0.097^{*}$ & $0.123^{*}$ & 0.008 & -0.009 & 0.003 & 0.011 & 0.014 & $0.119^{*}$ \\
\hline 14 & EDUC & $0.172 *$ & $0.156 *$ & $0.134 *$ & $0.192 *$ & 0.058 & 0.057 & 0.018 & 0.030 & $0.071^{*}$ & $0.193 *$ \\
\hline 15 & WCEO & $0.072 *$ & 0.057 & $0.087 *$ & 0.036 & 0.048 & $0.109^{*}$ & 0.005 & 0.026 & $0.089^{*}$ & 0.004 \\
\hline 16 & BINTERL & $0.145^{*}$ & $0.123^{*}$ & $0.156^{*}$ & $0.097^{*}$ & $0.227 *$ & $0.358^{*}$ & $0.114 *$ & $0.122 *$ & $0.291^{*}$ & -0.049 \\
\hline 17 & PCTINSTI & $-0.181^{*}$ & $-0.174 *$ & $-0.161^{*}$ & $-0.128 *$ & $-0.139 *$ & $-0.208^{*}$ & $-0.092 *$ & $-0.101 *$ & $-0.182^{*}$ & $-0.137 *$ \\
\hline 18 & ROA & $-0.125^{*}$ & $-0.094 *$ & $-0.150 *$ & $-0.094 *$ & 0.015 & -0.013 & -0.007 & 0.044 & 0.0001 & -0.014 \\
\hline 19 & LEV & $0.073^{*}$ & $0.066 *$ & 0.039 & 0.060 & 0.008 & 0.017 & 0.025 & -0.001 & 0.010 & $0.139^{*}$ \\
\hline 20 & HHI & -0.013 & -0.005 & $-0.066^{*}$ & $0.010^{*}$ & $0.131^{*}$ & $0.060^{*}$ & $0.168 *$ & $0.128^{*}$ & $0.065^{*}$ & 0.061 \\
\hline 21 & WBOD & $0.309^{*}$ & $0.268 *$ & $0.319^{*}$ & $0.164 *$ & $0.236^{*}$ & $0.441^{*}$ & $0.185^{*}$ & $0.171^{*}$ & $0.340^{*}$ & $0.193^{*}$ \\
\hline
\end{tabular}

\begin{tabular}{|c|c|c|c|c|c|c|c|c|c|c|c|c|}
\hline No & Variables & 11 & 12 & 13 & 14 & 15 & 16 & 17 & 18 & 19 & 20 & 21 \\
\hline 11 & BINDEP & 1 & & & & & & & & & & \\
\hline 12 & TENUR & $-0.205^{*}$ & 1 & & & & & & & & & \\
\hline 13 & AGE & 0.049 & $0.280^{*}$ & 1 & & & & & & & & \\
\hline 14 & EDUC & $0.107^{*}$ & $0.080^{*}$ & $0.096^{*}$ & 1 & & & & & & & \\
\hline 15 & WCEO & $0.079^{*}$ & -0.054 & $-0.091 *$ & $0.076^{*}$ & 1 & & & & & & \\
\hline 16 & BINTERL & $0.231 *$ & -0.059 & $-0.111^{*}$ & 0.007 & 0.034 & 1 & & & & & \\
\hline 17 & PCTINSTI & $-0.213^{*}$ & 0.009 & 0.020 & $-0.069^{*}$ & 0.050 & $-0.079^{*}$ & 1 & & & & \\
\hline 18 & ROA & -0.053 & $0.079 *$ & 0.015 & $-0.069 *$ & -0.022 & $-0.067 *$ & $-0.073^{*}$ & 1 & & & \\
\hline 19 & LEV & -0.007 & $-0.124 *$ & -0.052 & 0.061 & -0.027 & -0.020 & -0.033 & $-0.205^{*}$ & 1 & & \\
\hline 20 & HHI & 0.025 & -0.015 & -0.051 & -0.035 & -0.019 & 0.003 & -0.029 & 0.018 & 0.013 & 1 & \\
\hline 21 & WBOD & $0.408^{*}$ & -0.046 & -0.047 & 0.028 & $0.224 *$ & $0.292 *$ & $-0.165^{*}$ & 0.015 & $0.062 *$ & 0.013 & 1 \\
\hline
\end{tabular}

$t$ statistics in parentheses and ${ }^{*} p<0.01$. See Appendix for variables definitions. 
TABLE 3

Linear Regression for Board Networks and ESG Performance

\begin{tabular}{|c|c|c|c|c|c|c|c|c|c|c|c|}
\hline & ESG & ENV & SOC & GOV & ESG & ENV & SOC & GOV & ESG & ENV & SOC \\
\hline DEGREEt-1 & $\begin{array}{l}0.631 \\
(2.72)^{* * *}\end{array}$ & $\begin{array}{l}0.677 \\
(2.19) * *\end{array}$ & $\begin{array}{l}0.251 \\
(1.88)^{*}\end{array}$ & $\begin{array}{l}0.537 \\
(3.39) * * *\end{array}$ & & & & & & & \\
\hline CLOSEt-1 & & & & & $\begin{array}{l}0.237 \\
(2.94) * * *\end{array}$ & $\begin{array}{l}0.239 \\
(2.25)^{* *}\end{array}$ & $\begin{array}{l}0.155 \\
(1.69)^{*}\end{array}$ & $\begin{array}{l}0.204 \\
(3.83)^{* * *}\end{array}$ & & & \\
\hline EIGENt-1 & & & & & & & & & $\begin{array}{l}0.040 \\
(2.15)^{* *}\end{array}$ & $\begin{array}{l}0.032 \\
(1.70)^{*}\end{array}$ & $\begin{array}{l}0.016 \\
(2.10)^{* *}\end{array}$ \\
\hline BSIZE & $\begin{array}{l}1.643 \\
(15.14)^{* * *}\end{array}$ & $\begin{array}{l}1.841 \\
(13.00) * * *\end{array}$ & $\begin{array}{l}1.511 \\
(11.38)^{* * *}\end{array}$ & $\begin{array}{l}1.095 \\
(15.13)^{* * *}\end{array}$ & $\begin{array}{l}1.628 \\
(15.02)^{* * *}\end{array}$ & $\begin{array}{l}1.829 \\
(12.90) * * *\end{array}$ & $\begin{array}{l}1.491 \\
(11.26)^{* * *}\end{array}$ & $\begin{array}{l}1.082 \\
(14.94) * * *\end{array}$ & $\begin{array}{l}1.675 \\
(15.57)^{* * *}\end{array}$ & $\begin{array}{l}1.877 \\
(13.38)^{* * *}\end{array}$ & $\begin{array}{l}1.529 \\
(11.62)^{* * *}\end{array}$ \\
\hline BINDEP & $\begin{array}{l}0.176 \\
(9.57)^{* * *}\end{array}$ & $\begin{array}{l}0.232 \\
(9.61)^{* * * *}\end{array}$ & $\begin{array}{l}0.182 \\
(7.97)^{* * * *}\end{array}$ & $\begin{array}{l}0.063 \\
(4.82)^{* * * *}\end{array}$ & $\begin{array}{l}0.174 \\
(9.43)^{* * * *}\end{array}$ & $\begin{array}{l}0.230 \\
(9.56)^{* * *}\end{array}$ & $\begin{array}{l}0.178 \\
(7.72)^{* * *}\end{array}$ & $\begin{array}{l}0.061 \\
(4.63) * * *\end{array}$ & $\begin{array}{l}0.184 \\
(10.01)^{* * *}\end{array}$ & $\begin{array}{l}0.241 \\
(10.04)^{* * *}\end{array}$ & $\begin{array}{l}0.187 \\
(8.19) * * *\end{array}$ \\
\hline TENURE & $\begin{array}{l}-0.097 \\
(2.61)^{* * *}\end{array}$ & $\begin{array}{l}-0.098 \\
(2.01)^{* *}\end{array}$ & $\begin{array}{l}-0.050 \\
(1.05)\end{array}$ & $\begin{array}{l}-0.100 \\
(4.26)^{* * *}\end{array}$ & $\begin{array}{l}-0.093 \\
(2.52)^{* *}\end{array}$ & $\begin{array}{l}-0.095 \\
(1.96)^{*}\end{array}$ & $\begin{array}{l}-0.046 \\
(0.95)\end{array}$ & $\begin{array}{l}-0.097 \\
(4.16)^{* * *}\end{array}$ & $\begin{array}{l}-0.103 \\
(2.81)^{* * *}\end{array}$ & $\begin{array}{l}-0.106 \\
(2.19)^{* *}\end{array}$ & $\begin{array}{l}-0.054 \\
(1.12)\end{array}$ \\
\hline AGE & $\begin{array}{l}0.135 \\
(3.15)^{* * *}\end{array}$ & $\begin{array}{l}0.141 \\
(2.50)^{* *}\end{array}$ & $\begin{array}{l}0.129 \\
(2.56)^{* * *}\end{array}$ & $\begin{array}{l}0.121 \\
(4.16)^{* * *}\end{array}$ & $\begin{array}{l}0.132 \\
(3.08) * * *\end{array}$ & $\begin{array}{l}0.138 \\
(2.45)^{* *}\end{array}$ & $\begin{array}{l}0.126 \\
(2.51)^{* *}\end{array}$ & $\begin{array}{l}0.118 \\
(4.10)^{* * * *}\end{array}$ & $\begin{array}{l}0.137 \\
(3.19) * * *\end{array}$ & $\begin{array}{l}0.143 \\
(2.54) * *\end{array}$ & $\begin{array}{l}0.130 \\
(2.58) * * *\end{array}$ \\
\hline EDUCATION & $\begin{array}{l}0.417 \\
(2.01)^{* *}\end{array}$ & $\begin{array}{l}0.491 \\
(1.77)^{*}\end{array}$ & $\begin{array}{l}0.154 \\
(0.62)\end{array}$ & $\begin{array}{l}0.470 \\
(3.33)^{* * *}\end{array}$ & $\begin{array}{l}0.403 \\
(1.94)^{*}\end{array}$ & $\begin{array}{l}0.477 \\
(1.72)^{*}\end{array}$ & $\begin{array}{l}0.144 \\
(0.58)\end{array}$ & $\begin{array}{l}0.458 \\
(3.24)^{* * *}\end{array}$ & $\begin{array}{l}0.422 \\
(2.02)^{* *}\end{array}$ & $\begin{array}{l}0.496 \\
(1.79)^{*}\end{array}$ & $\begin{array}{l}0.155 \\
(0.63)\end{array}$ \\
\hline GENDER & $\begin{array}{l}1.955 \\
(1.66)^{*}\end{array}$ & $\begin{array}{l}1.722 \\
(1.16)\end{array}$ & $\begin{array}{l}3.367 \\
(2.25)^{* *}\end{array}$ & $\begin{array}{l}0.669 \\
(0.94)\end{array}$ & $\begin{array}{l}1.843 \\
(1.55)\end{array}$ & $\begin{array}{l}1.616 \\
(1.08)\end{array}$ & $\begin{array}{l}3.267 \\
(2.17)^{* *}\end{array}$ & $\begin{array}{l}0.572 \\
(0.80)\end{array}$ & $\begin{array}{l}2.066 \\
(1.74)^{*}\end{array}$ & $\begin{array}{l}1.838 \\
(1.23)\end{array}$ & $\begin{array}{l}3.406 \\
(2.27)^{* *}\end{array}$ \\
\hline BBOARD & $\begin{array}{l}0.015 \\
(1.83)^{*}\end{array}$ & $\begin{array}{l}0.026 \\
(2.32)^{* *}\end{array}$ & $\begin{array}{l}-0.003 \\
(0.27)\end{array}$ & $\begin{array}{l}0.009 \\
(1.48)\end{array}$ & $\begin{array}{l}0.015 \\
(1.74)^{*}\end{array}$ & $\begin{array}{l}0.026 \\
(2.27)^{* *}\end{array}$ & $\begin{array}{l}-0.004 \\
(0.41)\end{array}$ & $\begin{array}{l}0.008 \\
(1.38)\end{array}$ & $\begin{array}{l}0.019 \\
(2.29)^{* *}\end{array}$ & $\begin{array}{l}0.030 \\
(2.71)^{* * *}\end{array}$ & $\begin{array}{l}-0.001 \\
(0.09)\end{array}$ \\
\hline INSTI & $\begin{array}{l}-0.323 \\
(3.82)^{* * *}\end{array}$ & $\begin{array}{l}-0.409 \\
(3.48)^{* * *}\end{array}$ & $\begin{array}{l}-0.365 \\
(4.74)^{* * *}\end{array}$ & $\begin{array}{l}-0.104 \\
(1.94)^{*}\end{array}$ & $\begin{array}{l}-0.312 \\
(3.67)^{* * *}\end{array}$ & $\begin{array}{l}-0.398 \\
(3.38)^{* * *}\end{array}$ & $\begin{array}{l}-0.355 \\
(4.60)^{* * *}\end{array}$ & $\begin{array}{l}-0.095 \\
(1.75)^{*}\end{array}$ & $\begin{array}{l}-0.331 \\
(3.96)^{* * *}\end{array}$ & $\begin{array}{l}-0.418 \\
(3.58)^{* * *}\end{array}$ & $\begin{array}{l}-0.369 \\
(4.82)^{* * *}\end{array}$ \\
\hline ROA & $\begin{array}{l}-0.087 \\
(2.58)^{* * *}\end{array}$ & $\begin{array}{l}-0.078 \\
(1.86)^{*}\end{array}$ & $\begin{array}{l}-0.126 \\
(2.91)^{* * *}\end{array}$ & $\begin{array}{l}-0.045 \\
(2.46)^{* *}\end{array}$ & $\begin{array}{l}-0.088 \\
(2.56)^{* *}\end{array}$ & $\begin{array}{l}-0.078 \\
(1.84)^{*}\end{array}$ & $\begin{array}{l}-0.126 \\
(2.92)^{* * *}\end{array}$ & $\begin{array}{l}-0.046 \\
(2.43)^{* *}\end{array}$ & $\begin{array}{l}-0.085 \\
(2.50)^{* *}\end{array}$ & $\begin{array}{l}-0.075 \\
(1.78)^{*}\end{array}$ & $\begin{array}{l}-0.124 \\
(2.88)^{* * *}\end{array}$ \\
\hline LEV & $\begin{array}{l}-0.006 \\
(0.49)\end{array}$ & $\begin{array}{l}-0.011 \\
(0.63)\end{array}$ & $\begin{array}{l}-0.013 \\
(0.79)\end{array}$ & $\begin{array}{l}0.005 \\
(0.52)\end{array}$ & $\begin{array}{l}-0.006 \\
(0.50)\end{array}$ & $\begin{array}{l}-0.011 \\
(0.65)\end{array}$ & $\begin{array}{l}-0.012 \\
(0.78)\end{array}$ & $\begin{array}{l}0.004 \\
(0.50)\end{array}$ & $\begin{array}{l}-0.007 \\
(0.56)\end{array}$ & $\begin{array}{l}-0.012 \\
(0.69)\end{array}$ & $\begin{array}{l}-0.013 \\
(0.82)\end{array}$ \\
\hline Intercept & $\begin{array}{l}8.906 \\
(2.51)^{* * *}\end{array}$ & $\begin{array}{l}-5.305 \\
(1.15)\end{array}$ & $\begin{array}{l}14.784 \\
(3.60)^{* * *}\end{array}$ & $\begin{array}{l}38.098 \\
(16.63)^{* * *}\end{array}$ & $\begin{array}{l}10.402 \\
(2.94)^{* * *}\end{array}$ & $\begin{array}{l}-5.364 \\
(1.17)\end{array}$ & $\begin{array}{l}21.135 \\
(5.07)^{* * *}\end{array}$ & $\begin{array}{l}37.585 \\
(16.08)^{* * *}\end{array}$ & $\begin{array}{l}8.679 \\
(2.44)^{* * *}\end{array}$ & $\begin{array}{l}-5.599 \\
(1.21)\end{array}$ & $\begin{array}{l}14.599 \\
(3.55)^{* * * *}\end{array}$ \\
\hline Observations & 1724 & 1724 & 1724 & 1724 & 1724 & 1724 & 1724 & 1724 & 1724 & 1724 & 1724 \\
\hline R-squared & 0.404 & 0.337 & 0.366 & 0.323 & 0.405 & 0.337 & 0.367 & 0.325 & 0.402 & 0.335 & 0.366 \\
\hline \# Firms) & 199 & 199 & 199 & 199 & 199 & 199 & 199 & 199 & 199 & 199 & 199 \\
\hline
\end{tabular}

$t$ statistics in parentheses and ${ }^{*} p<0.1,{ }^{* *} p<0.05,{ }^{* * *} p<0.01$. See Appendix for variables definitions. 
TABLE 3 (continued)

Linear Regression for Board Networks and ESG Performance

\begin{tabular}{|c|c|c|c|c|c|c|c|c|}
\hline & ESG & ENV & SOC & GOV & ESG & ENV & SOC & GOV \\
\hline BETWEENt-1 & $\begin{array}{l}0.311 \\
(2.41)^{* *}\end{array}$ & $\begin{array}{l}0.283 \\
(1.69)^{*}\end{array}$ & $\begin{array}{l}0.174 \\
(1.91)^{*}\end{array}$ & $\begin{array}{l}0.266 \\
(3.02)^{* * *}\end{array}$ & & & & \\
\hline INFOt-1 & & & & & $\begin{array}{l}0.115 \\
(2.17)^{* *}\end{array}$ & $\begin{array}{l}0.144 \\
(2.05)^{* *}\end{array}$ & $\begin{array}{l}0.014 \\
(0.90)\end{array}$ & $\begin{array}{l}0.366 \\
(3.71)^{* * *}\end{array}$ \\
\hline BSIZE & $\begin{array}{l}1.643 \\
(15.03)^{* * *}\end{array}$ & $\begin{array}{l}1.847 \\
(12.96) * * *\end{array}$ & $\begin{array}{l}0.422 \\
(3.28) * * *\end{array}$ & $\begin{array}{l}1.095 \\
(15.02)^{* * *}\end{array}$ & $\begin{array}{l}0.445 \\
(5.06) * * *\end{array}$ & $\begin{array}{l}0.479 \\
(3.89)^{* * *}\end{array}$ & $\begin{array}{l}0.428 \\
(3.32)^{* * *}\end{array}$ & $\begin{array}{l}1.087 \\
(15.19) * * *\end{array}$ \\
\hline BINDEP & $\begin{array}{l}0.181 \\
(9.88) * * *\end{array}$ & $\begin{array}{l}0.238 \\
(9.95)^{* * *}\end{array}$ & $\begin{array}{l}0.045 \\
(2.35)^{* *}\end{array}$ & $\begin{array}{l}0.067 \\
(5.15)^{* * *}\end{array}$ & $\begin{array}{l}0.018 \\
(1.36)\end{array}$ & $\begin{array}{l}0.028 \\
(1.54)\end{array}$ & $\begin{array}{l}0.047 \\
(2.45)^{* *}\end{array}$ & $\begin{array}{l}0.064 \\
(4.88)^{* * * *}\end{array}$ \\
\hline TENURE & $\begin{array}{l}-0.099 \\
(2.68)^{* * *}\end{array}$ & $\begin{array}{l}-0.101 \\
(2.09)^{* *}\end{array}$ & $\begin{array}{l}-0.011 \\
(0.26)\end{array}$ & $\begin{array}{l}-0.102 \\
(4.34)^{* * *}\end{array}$ & $\begin{array}{l}-0.014 \\
(0.49)\end{array}$ & $\begin{array}{l}-0.003 \\
(0.08)\end{array}$ & $\begin{array}{l}-0.009 \\
(0.21)\end{array}$ & $\begin{array}{l}-0.097 \\
(4.13)^{* * *}\end{array}$ \\
\hline AGE & $\begin{array}{l}0.137 \\
(3.19)^{* * *}\end{array}$ & $\begin{array}{l}0.143 \\
(2.54)^{* *}\end{array}$ & $\begin{array}{l}0.147 \\
(3.38)^{* * * *}\end{array}$ & $\begin{array}{l}0.122 \\
(4.21)^{* * *}\end{array}$ & $\begin{array}{l}0.060 \\
(2.04)^{* *}\end{array}$ & $\begin{array}{l}0.021 \\
(0.52)\end{array}$ & $\begin{array}{l}0.149 \\
(3.43)^{* * *}\end{array}$ & $\begin{array}{l}0.117 \\
(4.05)^{* * *}\end{array}$ \\
\hline EDUCATION & $\begin{array}{l}0.427 \\
(2.04)^{* *}\end{array}$ & $\begin{array}{l}0.500 \\
(1.80)^{*}\end{array}$ & $\begin{array}{l}0.087 \\
(0.38)\end{array}$ & $\begin{array}{l}0.478 \\
(3.37)^{* * *}\end{array}$ & $\begin{array}{l}0.192 \\
(1.24)\end{array}$ & $\begin{array}{l}0.110 \\
(0.50)\end{array}$ & $\begin{array}{l}0.073 \\
(0.32)\end{array}$ & $\begin{array}{l}0.457 \\
(3.23)^{* * *}\end{array}$ \\
\hline GENDER & $\begin{array}{l}1.992 \\
(1.69)^{*}\end{array}$ & $\begin{array}{l}1.772 \\
(1.19)\end{array}$ & $\begin{array}{l}4.193 \\
(4.13)^{* * *}\end{array}$ & $\begin{array}{l}0.700 \\
(0.99)\end{array}$ & $\begin{array}{l}0.507 \\
(0.74)\end{array}$ & $\begin{array}{l}-0.906 \\
(0.94)\end{array}$ & $\begin{array}{l}4.283 \\
(4.22)^{* * *}\end{array}$ & $\begin{array}{l}0.595 \\
(0.83)\end{array}$ \\
\hline BBOARD & $\begin{array}{l}0.017 \\
(2.08)^{* *}\end{array}$ & $\begin{array}{l}0.028 \\
(2.57)^{* *}\end{array}$ & $\begin{array}{l}-0.006 \\
(0.82)\end{array}$ & $\begin{array}{l}0.010 \\
(1.78)^{*}\end{array}$ & $\begin{array}{l}-0.001 \\
(0.17)\end{array}$ & $\begin{array}{l}0.009 \\
(1.27)\end{array}$ & $\begin{array}{l}-0.005 \\
(0.70)\end{array}$ & $\begin{array}{l}0.009 \\
(1.49)\end{array}$ \\
\hline INSTI & $\begin{array}{l}-0.326 \\
(3.88)^{* * *}\end{array}$ & $\begin{array}{l}-0.412 \\
(3.53)^{* * * *}\end{array}$ & $\begin{array}{l}-0.145 \\
(2.43)^{* *}\end{array}$ & $\begin{array}{l}-0.107 \\
(1.99)^{* *}\end{array}$ & $\begin{array}{l}-0.107 \\
(2.67) * * *\end{array}$ & $\begin{array}{l}-0.137 \\
(2.43)^{* *}\end{array}$ & $\begin{array}{l}-0.142 \\
(2.39)^{* *}\end{array}$ & $\begin{array}{l}-0.098 \\
(1.81)^{*}\end{array}$ \\
\hline ROA & $\begin{array}{l}-0.088 \\
(2.59)^{* * *}\end{array}$ & $\begin{array}{l}-0.078 \\
(1.85)^{*}\end{array}$ & $\begin{array}{l}-0.068 \\
(3.27)^{* * *}\end{array}$ & $\begin{array}{l}-0.046 \\
(2.46)^{* *}\end{array}$ & $\begin{array}{l}-0.022 \\
(1.55)\end{array}$ & $\begin{array}{l}-0.004 \\
(0.19)\end{array}$ & $\begin{array}{l}-0.067 \\
(3.21)^{* * *}\end{array}$ & $\begin{array}{l}-0.045 \\
(2.41)^{* *}\end{array}$ \\
\hline LEV & $\begin{array}{l}-0.006 \\
(0.48)\end{array}$ & $\begin{array}{l}-0.011 \\
(0.64)\end{array}$ & $\begin{array}{l}0.029 \\
(1.48)\end{array}$ & $\begin{array}{l}0.005 \\
(0.53)\end{array}$ & $\begin{array}{l}0.030 \\
(2.16)^{* *}\end{array}$ & $\begin{array}{l}0.043 \\
(2.27)^{* *}\end{array}$ & $\begin{array}{l}0.028 \\
(1.43)\end{array}$ & $\begin{array}{l}0.005 \\
(0.52)\end{array}$ \\
\hline Intercept & $\begin{array}{l}8.875 \\
(2.51)^{* *}\end{array}$ & $\begin{array}{l}-5.400 \\
(1.17)\end{array}$ & $\begin{array}{l}38.263 \\
(8.81)^{* * * *}\end{array}$ & $\begin{array}{l}38.074 \\
(16.69)^{* * *}\end{array}$ & $\begin{array}{l}36.538 \\
(10.62)^{* * *}\end{array}$ & $\begin{array}{l}26.924 \\
(5.82)^{* * *}\end{array}$ & $\begin{array}{l}38.146 \\
(8.72)^{* * *}\end{array}$ & $\begin{array}{l}38.418 \\
(16.58)^{* * *}\end{array}$ \\
\hline Observations & 1724 & 1724 & 1724 & 1724 & 1724 & 1724 & 1724 & 1724 \\
\hline R-squared & 0.403 & 0.336 & 0.367 & 0.323 & 0.404 & 0.337 & 0.367 & 0.324 \\
\hline \# Firms & 199 & 199 & 199 & 199 & 199 & 199 & 199 & 199 \\
\hline
\end{tabular}


TABLE 4

Quadratic Regression for Board Networks and ESG Performance

\begin{tabular}{|c|c|c|c|c|c|c|c|c|c|c|c|c|}
\hline & ESG & ENV & SOC & GOV & ESG & ENV & SOC & GOV & ESG & ENV & SOC & GOV \\
\hline DEGREE $_{\mathrm{t}-1}$ & $\begin{array}{l}2.310 \\
(3.59)^{*} * *\end{array}$ & $\begin{array}{l}2.929 \\
(3.59)^{* * *}\end{array}$ & $\begin{array}{l}1.695 \\
(2.00)^{* *}\end{array}$ & $\begin{array}{l}0.713 \\
(1.76)^{*}\end{array}$ & & & & & & & & \\
\hline DEGREE $_{\mathrm{t}-1}{ }^{2}$ & $\begin{array}{l}-0.504 \\
(2.89)^{* * *}\end{array}$ & $\begin{array}{l}-0.676 \\
(3.15)^{* * *}\end{array}$ & $\begin{array}{l}-0.434 \\
(1.80)^{*}\end{array}$ & $\begin{array}{l}-0.053 \\
(0.47)\end{array}$ & & & & & & & & \\
\hline CLOSE $_{\mathrm{t}-1}$ & & & & & $\begin{array}{l}2.203 \\
(4.54)^{* * * *}\end{array}$ & $\begin{array}{l}2.685 \\
(4.15)^{* * *}\end{array}$ & $\begin{array}{l}2.166 \\
(3.84) * * *\end{array}$ & $\begin{array}{l}0.467 \\
(1.93) *\end{array}$ & & & & \\
\hline $\operatorname{CLOSE}_{\mathrm{t}-1}{ }^{2}$ & & & & & $\begin{array}{l}-0.082 \\
(4.16)^{* * * *}\end{array}$ & $\begin{array}{l}-0.102 \\
(3.86)^{* * *}\end{array}$ & $\begin{array}{l}-0.084 \\
(3.70)^{* * * *}\end{array}$ & $\begin{array}{l}-0.011 \\
(0.80)\end{array}$ & & & & \\
\hline EIGEN $_{t-1}$ & & & & & & & & & $\begin{array}{l}0.325 \\
(4.12)^{* * *}\end{array}$ & $\begin{array}{l}0.403 \\
(3.80)^{* * *}\end{array}$ & $\begin{array}{l}0.163 \\
(1.74)^{*}\end{array}$ & $\begin{array}{l}0.207 \\
(3.65)^{* * *}\end{array}$ \\
\hline EIGEN $_{t-1}^{2}$ & & & & & & & & & $\begin{array}{l}-0.012 \\
(4.60)^{* * *}\end{array}$ & $\begin{array}{l}-0.016 \\
(4.58)^{* * *}\end{array}$ & $\begin{array}{l}-0.007 \\
(2.24)^{* *}\end{array}$ & $\begin{array}{l}-0.006 \\
(3.11)^{* * *}\end{array}$ \\
\hline BSIZE & $\begin{array}{l}1.635 \\
(15.10) * * *\end{array}$ & $\begin{array}{l}1.830 \\
(12.97)^{* * * *}\end{array}$ & $\begin{array}{l}1.504 \\
(11.35)^{* * *}\end{array}$ & $\begin{array}{l}1.095 \\
(15.09)^{* * *}\end{array}$ & $\begin{array}{l}1.612 \\
(14.90) * * *\end{array}$ & $\begin{array}{l}1.808 \\
(12.78)^{* * *}\end{array}$ & $\begin{array}{l}1.474 \\
(11.16)^{* * *}\end{array}$ & $\begin{array}{l}1.080 \\
(14.92)^{* * * *}\end{array}$ & $\begin{array}{l}1.651 \\
(15.38) * * *\end{array}$ & $\begin{array}{l}1.846 \\
(13.20)^{* * * *}\end{array}$ & $\begin{array}{l}1.515 \\
(11.53)^{* * *}\end{array}$ & $\begin{array}{l}1.104 \\
(15.34)^{* * * *}\end{array}$ \\
\hline BINDEP & $\begin{array}{l}0.171 \\
(9.19)^{* * * *}\end{array}$ & $\begin{array}{l}0.224 \\
(9.21)^{* * * *}\end{array}$ & $\begin{array}{l}0.178 \\
(7.73)^{* * * *}\end{array}$ & $\begin{array}{l}0.063 \\
(4.75)^{* * *}\end{array}$ & $\begin{array}{l}0.178 \\
(9.70)^{* * * *}\end{array}$ & $\begin{array}{l}0.235 \\
(9.79) * * *\end{array}$ & $\begin{array}{l}0.182 \\
(7.94) * * *\end{array}$ & $\begin{array}{l}0.062 \\
(4.68)^{* * * *}\end{array}$ & $\begin{array}{l}0.174 \\
(9.40)^{* * * *}\end{array}$ & $\begin{array}{l}0.229 \\
(9.44)^{* * *}\end{array}$ & $\begin{array}{l}0.182 \\
(7.86)^{* * * *}\end{array}$ & $\begin{array}{l}0.063 \\
(4.77)^{* * *}\end{array}$ \\
\hline TENURE & $\begin{array}{l}-0.087 \\
(2.35)^{* *}\end{array}$ & $\begin{array}{l}-0.086 \\
(1.75)^{*}\end{array}$ & $\begin{array}{l}-0.042 \\
(0.87)\end{array}$ & $\begin{array}{l}-0.099 \\
(4.19)^{* * *}\end{array}$ & $\begin{array}{l}-0.088 \\
(2.39)^{* *}\end{array}$ & $\begin{array}{l}-0.088 \\
(1.83)^{*}\end{array}$ & $\begin{array}{l}-0.040 \\
(0.84)\end{array}$ & $\begin{array}{l}-0.096 \\
(4.13)^{* * *}\end{array}$ & $\begin{array}{l}-0.092 \\
(2.51)^{* *}\end{array}$ & $\begin{array}{l}-0.091 \\
(1.90)^{*}\end{array}$ & $\begin{array}{l}-0.047 \\
(0.99)\end{array}$ & $\begin{array}{l}-0.099 \\
(4.24)^{* * *}\end{array}$ \\
\hline AGE & $\begin{array}{l}0.135 \\
(3.15)^{* * *}\end{array}$ & $\begin{array}{l}0.141 \\
(2.50)^{* *}\end{array}$ & $\begin{array}{l}0.129 \\
(2.57)^{* * *}\end{array}$ & $\begin{array}{l}0.121 \\
(4.15)^{* * *}\end{array}$ & $\begin{array}{l}0.133 \\
(3.11)^{* * *}\end{array}$ & $\begin{array}{l}0.139 \\
(2.47)^{* *}\end{array}$ & $\begin{array}{l}0.127 \\
(2.52)^{* *}\end{array}$ & $\begin{array}{l}0.118 \\
(4.10)^{* * *}\end{array}$ & $\begin{array}{l}0.136 \\
(3.17)^{* * *}\end{array}$ & $\begin{array}{l}0.142 \\
(2.52)^{* *}\end{array}$ & $\begin{array}{l}0.129 \\
(2.57)^{* *}\end{array}$ & $\begin{array}{l}0.121 \\
(4.19) * * *\end{array}$ \\
\hline EDUCATION & $\begin{array}{l}0.367 \\
(1.75)^{*}\end{array}$ & $\begin{array}{l}0.423 \\
(1.52)\end{array}$ & $\begin{array}{l}0.111 \\
(0.45)\end{array}$ & $\begin{array}{l}0.465 \\
(3.28)^{* * *}\end{array}$ & $\begin{array}{l}0.406 \\
(1.95)^{*}\end{array}$ & $\begin{array}{l}0.481 \\
(1.73)^{*}\end{array}$ & $\begin{array}{l}0.147 \\
(0.60)\end{array}$ & $\begin{array}{l}0.459 \\
(3.24)^{* * *}\end{array}$ & $\begin{array}{l}0.424 \\
(2.04)^{* *}\end{array}$ & $\begin{array}{l}0.498 \\
(1.80)^{*}\end{array}$ & $\begin{array}{l}0.156 \\
(0.63)\end{array}$ & $\begin{array}{l}0.477 \\
(3.38)^{* * *}\end{array}$ \\
\hline GENDER & $\begin{array}{l}1.752 \\
(1.48)\end{array}$ & $\begin{array}{l}1.450 \\
(0.98)\end{array}$ & $\begin{array}{l}3.193 \\
(2.12)^{* *}\end{array}$ & $\begin{array}{l}0.648 \\
(0.91)\end{array}$ & $\begin{array}{l}1.754 \\
(1.47)\end{array}$ & $\begin{array}{l}1.506 \\
(1.00)\end{array}$ & $\begin{array}{l}3.177 \\
(2.12)^{* *}\end{array}$ & $\begin{array}{l}0.560 \\
(0.78)\end{array}$ & $\begin{array}{l}1.875 \\
(1.60)\end{array}$ & $\begin{array}{l}1.590 \\
(1.08)\end{array}$ & $\begin{array}{l}3.295 \\
(2.19)^{* *}\end{array}$ & $\begin{array}{l}0.667 \\
(0.94)\end{array}$ \\
\hline BBOARD & $\begin{array}{l}0.012 \\
(1.45)\end{array}$ & $\begin{array}{l}0.022 \\
(1.94)^{*}\end{array}$ & $\begin{array}{l}-0.005 \\
(0.53)\end{array}$ & $\begin{array}{l}0.008 \\
(1.41)\end{array}$ & $\begin{array}{l}0.016 \\
(1.94)^{*}\end{array}$ & $\begin{array}{l}0.028 \\
(2.46)^{* *}\end{array}$ & $\begin{array}{l}-0.002 \\
(0.24)\end{array}$ & $\begin{array}{l}0.008 \\
(1.42)\end{array}$ & $\begin{array}{l}0.015 \\
(1.84)^{*}\end{array}$ & $\begin{array}{l}0.025 \\
(2.28)^{* * *}\end{array}$ & $\begin{array}{l}-0.003 \\
(0.31)\end{array}$ & $\begin{array}{l}0.009 \\
(1.62)\end{array}$ \\
\hline INSTI & $\begin{array}{l}-0.313 \\
(3.67)^{* * *}\end{array}$ & $\begin{array}{l}-0.395 \\
(3.33)^{* * *}\end{array}$ & $\begin{array}{l}-0.356 \\
(4.60)^{* * *}\end{array}$ & $\begin{array}{l}-0.103 \\
(1.92)^{*}\end{array}$ & $\begin{array}{l}-0.310 \\
(3.63)^{* * *}\end{array}$ & $\begin{array}{l}-0.396 \\
(3.34)^{* * *}\end{array}$ & $\begin{array}{l}-0.353 \\
(4.51)^{* * *}\end{array}$ & $\begin{array}{l}-0.095 \\
(1.74)^{*}\end{array}$ & $\begin{array}{l}-0.323 \\
(3.85)^{* * *}\end{array}$ & $\begin{array}{l}-0.407 \\
(3.48)^{* * *}\end{array}$ & $\begin{array}{l}-0.364 \\
(4.75)^{* * *}\end{array}$ & $\begin{array}{l}-0.106 \\
(1.98)^{* *}\end{array}$ \\
\hline ROA & $\begin{array}{l}-0.091 \\
(2.69)^{* * *}\end{array}$ & $\begin{array}{l}-0.082 \\
(1.97)^{* *}\end{array}$ & $\begin{array}{l}-0.128 \\
(2.98)^{* * *}\end{array}$ & $\begin{array}{l}-0.046 \\
(2.48)^{* *}\end{array}$ & $\begin{array}{l}-0.085 \\
(2.50)^{* *}\end{array}$ & $\begin{array}{l}-0.075 \\
(1.78)^{*}\end{array}$ & $\begin{array}{l}-0.124 \\
(2.88) * * *\end{array}$ & $\begin{array}{l}-0.045 \\
(2.41)^{* *}\end{array}$ & $\begin{array}{l}-0.088 \\
(2.61)^{* * *}\end{array}$ & $\begin{array}{l}-0.080 \\
(1.90)^{*}\end{array}$ & $\begin{array}{l}-0.127 \\
(2.93)^{* * *}\end{array}$ & $\begin{array}{l}-0.045 \\
(2.44)^{* *}\end{array}$ \\
\hline LEV & $\begin{array}{l}-0.005 \\
(0.41)\end{array}$ & $\begin{array}{l}-0.010 \\
(0.56)\end{array}$ & $\begin{array}{l}-0.012 \\
(0.74)\end{array}$ & $\begin{array}{l}0.005 \\
(0.53)\end{array}$ & $\begin{array}{l}-0.005 \\
(0.41)\end{array}$ & $\begin{array}{l}-0.010 \\
(0.57)\end{array}$ & $\begin{array}{l}-0.011 \\
(0.71)\end{array}$ & $\begin{array}{l}0.005 \\
(0.52)\end{array}$ & $\begin{array}{l}-0.007 \\
(0.51)\end{array}$ & $\begin{array}{l}-0.011 \\
(0.65)\end{array}$ & $\begin{array}{l}-0.013 \\
(0.79)\end{array}$ & $\begin{array}{l}0.004 \\
(0.47)\end{array}$ \\
\hline Intercept & $\begin{array}{l}8.284 \\
(2.34)^{* *}\end{array}$ & $\begin{array}{l}-6.139 \\
(1.33)\end{array}$ & $\begin{array}{l}14.249 \\
(3.47)^{* * *}\end{array}$ & $\begin{array}{l}38.033 \\
(16.61)^{* * *}\end{array}$ & $\begin{array}{l}0.118 \\
(0.03)\end{array}$ & $\begin{array}{l}-18.161 \\
(3.18)^{* * *}\end{array}$ & $\begin{array}{l}10.617 \\
(2.11)^{* *}\end{array}$ & $\begin{array}{l}36.209 \\
(12.66)^{* * *}\end{array}$ & $\begin{array}{l}9.051 \\
(2.56) * *\end{array}$ & $\begin{array}{l}-5.117 \\
(1.11)\end{array}$ & $\begin{array}{l}14.816 \\
(3.60)^{* * *}\end{array}$ & $\begin{array}{l}38.206 \\
(16.71)^{* * *}\end{array}$ \\
\hline Year dummies & Yes & Yes & Yes & Yes & Yes & Yes & Yes & Yes & Yes & Yes & Yes & Yes \\
\hline Sector dummies & Yes & Yes & Yes & Yes & Yes & Yes & Yes & Yes & Yes & Yes & Yes & Yes \\
\hline Observations & 1724 & 1724 & 1724 & 1724 & 1724 & 1724 & 1724 & 1724 & 1724 & 1724 & 1724 & 1724 \\
\hline R-squared & 0.407 & 0.340 & 0.368 & 0.324 & 0.410 & 0.343 & 0.371 & 0.325 & 0.407 & 0.340 & 0.367 & 0.324 \\
\hline \# Firms & 199 & 199 & 199 & 199 & 199 & 199 & 199 & 199 & 199 & 199 & 199 & 199 \\
\hline
\end{tabular}


Table 4 (continued)

Quadratic Regression of Board Networks on ESG

\begin{tabular}{|c|c|c|c|c|c|c|c|c|}
\hline & ESG & ENV & SOC & GOV & ESG & ENV & SOC & GOV \\
\hline BETWEEN $_{\mathrm{t}-1}$ & $\begin{array}{l}0.774 \\
(2.76)^{* * *}\end{array}$ & $\begin{array}{l}1.117 \\
(3.01)^{* * *}\end{array}$ & $\begin{array}{l}-0.562 \\
(2.24)^{* *}\end{array}$ & $\begin{array}{l}0.501 \\
(2.59)^{* * * *}\end{array}$ & & & & \\
\hline BETWEEN $_{\mathrm{t}-1}{ }^{2}$ & $\begin{array}{l}-0.074 \\
(1.94)^{*}\end{array}$ & $\begin{array}{l}-0.133 \\
(2.68)^{* * *}\end{array}$ & $\begin{array}{l}0.110 \\
(3.37)^{* * * *}\end{array}$ & $\begin{array}{l}-0.037 \\
(1.44)\end{array}$ & & & & \\
\hline $\mathrm{INFO}_{\mathrm{t}-1}$ & & & & & $\begin{array}{l}1.433 \\
(2.58) * * *\end{array}$ & $\begin{array}{l}2.103 \\
(2.69) * * *\end{array}$ & $\begin{array}{l}0.966 \\
(1.16)\end{array}$ & $\begin{array}{l}1.687 \\
(2.55)^{* *}\end{array}$ \\
\hline $\mathrm{INFO}_{\mathrm{t}-1}{ }^{2}$ & & & & & $\begin{array}{l}-0.224 \\
(2.41)^{* *}\end{array}$ & $\begin{array}{l}-0.333 \\
(2.55)^{* *}\end{array}$ & $\begin{array}{l}-0.167 \\
(1.20)\end{array}$ & $\begin{array}{l}-0.148 \\
(1.03)\end{array}$ \\
\hline BSIZE & $\begin{array}{l}1.650 \\
(15.11)^{* * *}\end{array}$ & $\begin{array}{l}1.860 \\
(13.08)^{* * *}\end{array}$ & $\begin{array}{l}0.406 \\
(3.17)^{* * *}\end{array}$ & $\begin{array}{l}1.099 \\
(15.07) * * *\end{array}$ & $\begin{array}{l}0.440 \\
(5.00)^{* * *}\end{array}$ & $\begin{array}{l}0.472 \\
(3.83)^{* * *}\end{array}$ & $\begin{array}{l}0.423 \\
(3.29)^{* * *}\end{array}$ & $\begin{array}{l}1.095 \\
(15.37)^{* * * *}\end{array}$ \\
\hline BINDEP & $\begin{array}{l}0.176 \\
(9.46)^{* * *}\end{array}$ & $\begin{array}{l}0.229 \\
(9.42) * * *\end{array}$ & $\begin{array}{l}0.048 \\
(2.49) * *\end{array}$ & $\begin{array}{l}0.065 \\
(4.93)^{* * *}\end{array}$ & $\begin{array}{l}0.020 \\
(1.50)\end{array}$ & $\begin{array}{l}0.031 \\
(1.70)^{*}\end{array}$ & $\begin{array}{l}0.049 \\
(2.51)^{* *}\end{array}$ & $\begin{array}{l}0.062 \\
(4.72)^{* * *}\end{array}$ \\
\hline TENURE & $\begin{array}{l}-0.096 \\
(2.61)^{* * *}\end{array}$ & $\begin{array}{l}-0.097 \\
(2.00)^{* *}\end{array}$ & $\begin{array}{l}-0.002 \\
(0.05)\end{array}$ & $\begin{array}{l}-0.101 \\
(4.28)^{* * *}\end{array}$ & $\begin{array}{l}-0.015 \\
(0.51)\end{array}$ & $\begin{array}{l}-0.004 \\
(0.11)\end{array}$ & $\begin{array}{l}-0.009 \\
(0.22)\end{array}$ & $\begin{array}{l}-0.097 \\
(4.15)^{* * *}\end{array}$ \\
\hline AGE & $\begin{array}{l}0.138 \\
(3.20)^{* * *}\end{array}$ & $\begin{array}{l}0.144 \\
(2.56)^{* *}\end{array}$ & $\begin{array}{l}0.143 \\
(3.30)^{* * *}\end{array}$ & $\begin{array}{l}0.122 \\
(4.22)^{* * *}\end{array}$ & $\begin{array}{l}0.063 \\
(2.13)^{* *}\end{array}$ & $\begin{array}{l}0.025 \\
(0.61)\end{array}$ & $\begin{array}{l}0.151 \\
(3.48)^{* * * *}\end{array}$ & $\begin{array}{l}0.113 \\
(3.92)^{* * *}\end{array}$ \\
\hline EDUCATION & $\begin{array}{l}0.391 \\
(1.87)^{*}\end{array}$ & $\begin{array}{l}0.436 \\
(1.57)\end{array}$ & $\begin{array}{l}0.137 \\
(0.60)\end{array}$ & $\begin{array}{l}0.460 \\
(3.22)^{* * *}\end{array}$ & $\begin{array}{l}0.195 \\
(1.25)\end{array}$ & $\begin{array}{l}0.113 \\
(0.52)\end{array}$ & $\begin{array}{l}0.074 \\
(0.32)\end{array}$ & $\begin{array}{l}0.468 \\
(3.31)^{* * *}\end{array}$ \\
\hline GENDER & $\begin{array}{l}1.883 \\
(1.60)\end{array}$ & $\begin{array}{l}1.576 \\
(1.06)\end{array}$ & $\begin{array}{l}4.349 \\
(4.29) * * *\end{array}$ & $\begin{array}{l}0.645 \\
(0.91)\end{array}$ & $\begin{array}{l}0.567 \\
(0.82)\end{array}$ & $\begin{array}{l}-0.816 \\
(0.85)\end{array}$ & $\begin{array}{l}4.327 \\
(4.26)^{* * *}\end{array}$ & $\begin{array}{l}0.534 \\
(0.75)\end{array}$ \\
\hline BBOARD & $\begin{array}{l}0.015 \\
(1.87)^{*}\end{array}$ & $\begin{array}{l}0.025 \\
(2.28)^{* *}\end{array}$ & $\begin{array}{l}-0.005 \\
(0.63)\end{array}$ & $\begin{array}{l}0.009 \\
(1.61)\end{array}$ & $\begin{array}{l}0.000 \\
(0.01)\end{array}$ & $\begin{array}{l}0.011 \\
(1.46)\end{array}$ & $\begin{array}{l}-0.005 \\
(0.61)\end{array}$ & $\begin{array}{l}0.008 \\
(1.35)\end{array}$ \\
\hline INSTI & $\begin{array}{l}-0.324 \\
(3.85)^{* * *}\end{array}$ & $\begin{array}{l}-0.410 \\
(3.50)^{* * *}\end{array}$ & $\begin{array}{l}-0.146 \\
(2.46) * *\end{array}$ & $\begin{array}{l}-0.106 \\
(1.97)^{* *}\end{array}$ & $\begin{array}{l}-0.110 \\
(2.76)^{* * *}\end{array}$ & $\begin{array}{l}-0.142 \\
(2.52)^{* *}\end{array}$ & $\begin{array}{l}-0.145 \\
(2.43)^{* *}\end{array}$ & $\begin{array}{l}-0.096 \\
(1.77)^{*}\end{array}$ \\
\hline ROA & $\begin{array}{l}-0.090 \\
(2.65)^{* * *}\end{array}$ & $\begin{array}{l}-0.082 \\
(1.94)^{*}\end{array}$ & $\begin{array}{l}-0.067 \\
(3.24)^{* * *}\end{array}$ & $\begin{array}{l}-0.047 \\
(2.51)^{* *}\end{array}$ & $\begin{array}{l}-0.022 \\
(1.58)\end{array}$ & $\begin{array}{l}-0.004 \\
(0.22)\end{array}$ & $\begin{array}{l}-0.067 \\
(3.22)^{* * *}\end{array}$ & $\begin{array}{l}-0.047 \\
(2.51)^{* *}\end{array}$ \\
\hline LEV & $\begin{array}{l}-0.006 \\
(0.48)\end{array}$ & $\begin{array}{l}-0.011 \\
(0.64)\end{array}$ & $\begin{array}{l}0.030 \\
(1.54)\end{array}$ & $\begin{array}{l}0.005 \\
(0.54)\end{array}$ & $\begin{array}{l}0.029 \\
(2.09)^{* *}\end{array}$ & $\begin{array}{l}0.042 \\
(2.18)^{* *}\end{array}$ & $\begin{array}{l}0.028 \\
(1.40)\end{array}$ & $\begin{array}{l}0.004 \\
(0.42)\end{array}$ \\
\hline Intercept & $\begin{array}{l}9.015 \\
(2.55)^{* *}\end{array}$ & $\begin{array}{l}-5.149 \\
(1.12)\end{array}$ & $\begin{array}{l}38.546 \\
(8.88)^{* * * *}\end{array}$ & $\begin{array}{l}38.144 \\
(16.74)^{* * *}\end{array}$ & $\begin{array}{l}35.730 \\
(10.33)^{* * *}\end{array}$ & $\begin{array}{l}25.703 \\
(5.53)^{* * * *}\end{array}$ & $\begin{array}{l}37.557 \\
(8.52)^{* * *}\end{array}$ & $\begin{array}{l}39.345 \\
(15.99)^{* * * *}\end{array}$ \\
\hline Year dummies & Yes & Yes & Yes & Yes & Yes & Yes & Yes & Yes \\
\hline Sector dummies & Yes & Yes & Yes & Yes & Yes & Yes & Yes & Yes \\
\hline Observations & 1724 & 1724 & 1724 & 1724 & 1724 & 1724 & 1724 & 1724 \\
\hline R-squared & 0.405 & 0.339 & 0.368 & 0.323 & 0.404 & 0.337 & 0.367 & 0.327 \\
\hline \# Firms & 199 & 199 & 199 & 199 & 199 & 199 & 199 & 199 \\
\hline
\end{tabular}

$t$ statistics in parentheses and ${ }^{*} p<0.1,{ }^{* *} p<0.05,{ }^{* * *} p<0.01$. See Appendix for variables definitions. 
Table 5

Two-Stage Least Square (2SLS) Regression

Panel A. First Stage Regression: Determinants of Board Networks

\begin{tabular}{|c|c|c|c|c|c|}
\hline & DEGREE & CLOSE & EIGEN & BETWEEN & INFO \\
\hline DEGREE $_{\mathrm{t}-1}$ & $\begin{array}{l}0.008 \\
(43.34) * * *\end{array}$ & & & & \\
\hline $\operatorname{CLOSE}_{\mathrm{t}-1}$ & & $\begin{array}{l}0.007 \\
(30.70) * * *\end{array}$ & & & \\
\hline EIGEN $_{\mathrm{t}-1}$ & & & $\begin{array}{l}0.006 \\
(20.29)^{* * *}\end{array}$ & & \\
\hline BETWEEN $_{t-1}$ & & & & $\begin{array}{l}0.007 \\
(20.97) * * *\end{array}$ & \\
\hline $\mathrm{INFO}_{\mathrm{t}-1}$ & & & & & $\begin{array}{l}0.007 \\
(23.32)^{* * * *}\end{array}$ \\
\hline HHI & $\begin{array}{l}0.018 \\
(7.15)^{* * *}\end{array}$ & $\begin{array}{l}0.038 \\
(4.68)^{* * *}\end{array}$ & $\begin{array}{l}0.254 \\
(7.72)^{* * *}\end{array}$ & $\begin{array}{l}0.036 \\
(6.40)^{* * *}\end{array}$ & $\begin{array}{l}0.009 \\
(2.07)^{* *}\end{array}$ \\
\hline PCTWBOD & $\begin{array}{l}0.0002 \\
(2.49)^{* *}\end{array}$ & $\begin{array}{l}0.001 \\
(2.21)^{* *}\end{array}$ & $\begin{array}{l}0.002 \\
(2.73)^{* * *}\end{array}$ & $\begin{array}{l}0.001 \\
(3.42)^{* * *}\end{array}$ & $\begin{array}{l}0.0002 \\
(1.77)^{*}\end{array}$ \\
\hline BSIZE & $\begin{array}{l}0.000 \\
(4.01)^{* * *}\end{array}$ & $\begin{array}{l}0.001 \\
(4.42)^{* * *}\end{array}$ & $\begin{array}{l}0.002 \\
(3.27)^{* * *}\end{array}$ & $\begin{array}{l}0.000 \\
(3.04)^{* * *}\end{array}$ & $\begin{array}{l}0.001 \\
(4.82)^{* * *}\end{array}$ \\
\hline BINDEP & $\begin{array}{l}0.000 \\
(2.12)^{* *}\end{array}$ & $\begin{array}{l}0.000 \\
(2.50)^{* *}\end{array}$ & $\begin{array}{l}0.000 \\
(1.35)\end{array}$ & $\begin{array}{l}0.000 \\
(1.71)^{*}\end{array}$ & $\begin{array}{l}0.000 \\
(2.32)^{* *}\end{array}$ \\
\hline TENURE & $\begin{array}{l}0.000 \\
(0.37)\end{array}$ & $\begin{array}{l}-0.000 \\
(1.47)\end{array}$ & $\begin{array}{l}0.000 \\
(0.36)\end{array}$ & $\begin{array}{l}0.000 \\
(0.01)\end{array}$ & $\begin{array}{l}-0.000 \\
(1.71)^{*}\end{array}$ \\
\hline AGE & $\begin{array}{l}-0.000 \\
(1.31)\end{array}$ & $\begin{array}{l}0.000 \\
(0.72)\end{array}$ & $\begin{array}{l}-0.000 \\
(0.42)\end{array}$ & $\begin{array}{l}-0.000 \\
(1.13)\end{array}$ & $\begin{array}{l}0.000 \\
(0.77)\end{array}$ \\
\hline EDUCATION & $\begin{array}{l}-0.000 \\
(0.24)\end{array}$ & $\begin{array}{l}-0.000 \\
(0.45)\end{array}$ & $\begin{array}{l}-0.001 \\
(1.06)\end{array}$ & $\begin{array}{l}-0.000 \\
(0.30)\end{array}$ & $\begin{array}{l}-0.000 \\
(0.29)\end{array}$ \\
\hline GENDER & $\begin{array}{l}0.000 \\
(0.47)\end{array}$ & $\begin{array}{l}0.000 \\
(0.24)\end{array}$ & $\begin{array}{l}-0.003 \\
(0.65)\end{array}$ & $\begin{array}{l}-0.000 \\
(0.09)\end{array}$ & $\begin{array}{l}0.001 \\
(0.70)\end{array}$ \\
\hline BBOARD & $\begin{array}{l}0.000 \\
(3.66)^{* * *}\end{array}$ & $\begin{array}{l}0.000 \\
(2.75)^{* * *}\end{array}$ & $\begin{array}{l}0.000 \\
(1.46)\end{array}$ & $\begin{array}{l}0.000 \\
(2.96)^{* * *}\end{array}$ & $\begin{array}{l}0.000 \\
(2.59) * * *\end{array}$ \\
\hline INSTI & $\begin{array}{l}-0.000 \\
(0.50)\end{array}$ & $\begin{array}{l}-0.000 \\
(2.60)^{* * *}\end{array}$ & $\begin{array}{l}-0.000 \\
(0.48)\end{array}$ & $\begin{array}{l}-0.000 \\
(0.16)\end{array}$ & $\begin{array}{l}-0.000 \\
(2.23)^{* *}\end{array}$ \\
\hline ROA & $\begin{array}{l}0.000 \\
(0.16)\end{array}$ & $\begin{array}{l}0.000 \\
(0.22)\end{array}$ & $\begin{array}{l}-0.000 \\
(0.26)\end{array}$ & $\begin{array}{l}-0.000 \\
(0.11)\end{array}$ & $\begin{array}{l}0.000 \\
(0.30)\end{array}$ \\
\hline LEV & $\begin{array}{l}-0.000 \\
(0.98)\end{array}$ & $\begin{array}{l}-0.000 \\
(1.45)\end{array}$ & $\begin{array}{l}0.000 \\
(0.49)\end{array}$ & $\begin{array}{l}-0.000 \\
(0.84)\end{array}$ & $\begin{array}{l}-0.000 \\
(1.85)^{*}\end{array}$ \\
\hline Intercept & $\begin{array}{l}-0.005 \\
(2.39)^{* *}\end{array}$ & $\begin{array}{l}0.020 \\
(2.97)^{* * *}\end{array}$ & $\begin{array}{l}-0.081 \\
(5.57)^{* * *}\end{array}$ & $\begin{array}{l}-0.009 \\
(2.26)^{* *}\end{array}$ & $\begin{array}{l}0.019 \\
(4.77) * * *\end{array}$ \\
\hline Year dummies & Yes & Yes & Yes & Yes & Yes \\
\hline Sector dummies & Yes & Yes & Yes & Yes & Yes \\
\hline Observations & 1724 & 1724 & 1724 & 1724 & 1724 \\
\hline R-squared & 0.710 & 0.703 & 0.521 & 0.560 & 0.651 \\
\hline
\end{tabular}

HHI represents product market concentration and PCTWBOD represents the percentage of women boards. $t$ statistics in parentheses and ${ }^{*} p<0.1,{ }^{* *} p<0.05,{ }^{* * *} p<0.01$. See Appendix for variables definitions. 
Panel B

Second Stage Regression: Linear Regression of Board Networks on ESG

\begin{tabular}{|c|c|c|c|c|c|c|c|c|c|c|c|c|}
\hline & ESG & ENV & SOC & GOV & ESG & ENV & SOC & GOV & ESG & ENV & SOC & GOV \\
\hline DEGREE $_{\mathrm{t}-1}$ & $\begin{array}{l}0.642 \\
(2.69) * * *\end{array}$ & $\begin{array}{l}0.696 \\
(2.20)^{* *}\end{array}$ & $\begin{array}{l}0.241 \\
(0.84)\end{array}$ & $\begin{array}{l}0.535 \\
(3.31)^{* * * *}\end{array}$ & & & & & & & & \\
\hline $\operatorname{CLOSE}_{\mathrm{t}-1}$ & & & & & $\begin{array}{l}0.242 \\
(3.06)^{* * *}\end{array}$ & $\begin{array}{l}0.247 \\
(2.35)^{* * *}\end{array}$ & $\begin{array}{l}0.152 \\
(1.60)\end{array}$ & $\begin{array}{l}0.202 \\
(3.76)^{* * *}\end{array}$ & & & & \\
\hline EIGEN $_{t-1}$ & & & & & & & & & $\begin{array}{l}0.043 \\
(1.83)^{*}\end{array}$ & $\begin{array}{l}0.037 \\
(1.74)^{*}\end{array}$ & $\begin{array}{l}0.006 \\
(0.14)\end{array}$ & $\begin{array}{l}0.056 \\
(2.18)^{* *}\end{array}$ \\
\hline Intercept & $\begin{array}{l}7.480 \\
(2.46)^{* * *}\end{array}$ & $\begin{array}{l}-6.428 \\
(1.59)\end{array}$ & $\begin{array}{l}12.987 \\
(3.55)^{* * * *}\end{array}$ & $\begin{array}{l}37.110 \\
(17.98)^{* * *}\end{array}$ & $\begin{array}{l}5.865 \\
(1.92)^{*}\end{array}$ & $\begin{array}{l}-8.107 \\
(1.99)^{* *}\end{array}$ & $\begin{array}{l}12.081 \\
(3.28)^{* * * *}\end{array}$ & $\begin{array}{l}35.762 \\
(17.23) * * *\end{array}$ & $\begin{array}{l}7.241 \\
(2.37)^{* * *}\end{array}$ & $\begin{array}{l}-6.730 \\
(1.66)^{*}\end{array}$ & $\begin{array}{l}12.794 \\
(3.50)^{* * * *}\end{array}$ & $\begin{array}{l}37.004 \\
(17.89)^{* * * *}\end{array}$ \\
\hline Control variables & Yes & Yes & Yes & Yes & Yes & Yes & Yes & Yes & Yes & Yes & Yes & Yes \\
\hline Year dummies & Yes & Yes & Yes & Yes & Yes & Yes & Yes & Yes & Yes & Yes & Yes & Yes \\
\hline Sector dummies & Yes & Yes & Yes & Yes & Yes & Yes & Yes & Yes & Yes & Yes & Yes & Yes \\
\hline Observations & 1724 & 1724 & 1724 & 1724 & 1724 & 1724 & 1724 & 1724 & 1724 & 1724 & 1724 & 1724 \\
\hline R-squared & 0.404 & 0.338 & 0.364 & 0.323 & 0.405 & 0.338 & 0.365 & 0.324 & 0.402 & 0.336 & 0.364 & 0.321 \\
\hline \# Firms & 199 & 199 & 199 & 199 & 199 & 199 & 199 & 199 & 199 & 199 & 199 & 199 \\
\hline
\end{tabular}

$t$ statistics in parentheses and ${ }^{*} p<0.1,{ }^{* *} p<0.05,{ }^{* * *} p<0.01$. See Appendix for variables definitions.

Panel B (continued)

Second Stage Regression: Linear Regression of Board Networks on ESG

\begin{tabular}{lllllllll}
\hline & ESG & ENV & SOC & GOV & ESG & ENV & SOC & GOV \\
\hline BETWEEN $_{\mathrm{t}-1}$ & 0.318 & 0.292 & 0.312 & 0.271 & & & & \\
& $(2.42)^{* *}$ & $(1.68)^{*}$ & $(1.99)^{* *}$ & $(3.04)^{* * *}$ & & & & \\
INFO & & & & & 0.451 & 0.458 & 0.324 & 0.362 \\
& & & & & $(2.96)^{* * *}$ & $(2.26)^{* *}$ & $(1.77)^{* *}$ & $(3.50)^{* * *}$ \\
Intercept & 7.395 & -6.578 & 14.567 & 37.045 & 6.849 & -7.100 & 12.683 & 36.589 \\
& $(2.43)^{* *}$ & $(1.63)$ & $(4.13)^{* * *}$ & $(17.94)^{* * *}$ & $(2.25)^{* *}$ & $(1.76)^{*}$ & $(3.48)^{* * *}$ & $(17.75)^{* * *}$ \\
Control variables & Yes & Yes & Yes & Yes & Yes & Yes & Yes & Yes \\
Year dummies & Yes & Yes & Yes & Yes & Yes & Yes & Yes & Yes \\
Sector dummies & Yes & Yes & Yes & Yes & Yes & Yes & Yes & Yes \\
Observations & 1724 & 1724 & 1724 & 1724 & 1724 & 1724 & 1724 & 1724 \\
R-squared & 0.404 & 0.337 & 0.364 & 0.322 & 0.405 & 0.338 & 0.365 & 0.324 \\
\# Firms & 199 & 199 & 199 & 199 & 199 & 199 & 199 & 199 \\
\hline
\end{tabular}

$t$ statistics in parentheses and ${ }^{*} p<0.1,{ }^{* *} p<0.05,{ }^{* * *} p<0.01$. See Appendix for variables definitions. 


\section{Panel C}

Second Stage Regression: Quadratic Regression of Board Networks on ESG

\begin{tabular}{|c|c|c|c|c|c|c|c|c|c|c|c|c|}
\hline & ESG & ENV & SOC & GOV & ESG & ENV & SOC & GOV & ESG & ENV & SOC & GOV \\
\hline DEGREE $_{\mathrm{t}-1}$ & $\begin{array}{l}2.310 \\
(3.59)^{* * * *}\end{array}$ & $\begin{array}{l}2.929 \\
(3.59)^{* * * *}\end{array}$ & $\begin{array}{l}1.695 \\
(2.00)^{* * *}\end{array}$ & $\begin{array}{l}0.713 \\
(1.76) *\end{array}$ & & & & & & & & \\
\hline DEGREE $_{\mathrm{t}-1}{ }^{2}$ & $\begin{array}{l}-0.504 \\
(2.89)^{* * *}\end{array}$ & $\begin{array}{l}-0.676 \\
(3.15)^{* * *}\end{array}$ & $\begin{array}{l}-0.434 \\
(1.80)^{*}\end{array}$ & $\begin{array}{l}-0.053 \\
(0.47)\end{array}$ & & & & & & & & \\
\hline $\operatorname{CLOSE}_{\mathrm{t}-1}$ & & & & & $\begin{array}{l}2.203 \\
(4.54)^{* * *}\end{array}$ & $\begin{array}{l}2.685 \\
(4.15)^{* * * *}\end{array}$ & $\begin{array}{l}2.166 \\
(3.84)^{* * *}\end{array}$ & $\begin{array}{l}0.467 \\
(1.93)^{*}\end{array}$ & & & & \\
\hline $\operatorname{CLOSE}_{\mathrm{t}-1}{ }^{2}$ & & & & & $\begin{array}{l}-0.082 \\
(4.16)^{* * * *}\end{array}$ & $\begin{array}{l}-0.102 \\
(3.86)^{* * *}\end{array}$ & $\begin{array}{l}-0.084 \\
(3.70)^{* * *}\end{array}$ & $\begin{array}{l}-0.011 \\
(0.80)\end{array}$ & & & & \\
\hline EIGEN $_{t-1}$ & & & & & & & & & $\begin{array}{l}0.325 \\
(4.12)^{* * *}\end{array}$ & $\begin{array}{l}0.403 \\
(3.80)^{* * *}\end{array}$ & $\begin{array}{l}0.163 \\
(1.74)^{*}\end{array}$ & $\begin{array}{l}0.207 \\
(3.65)^{* * *}\end{array}$ \\
\hline EIGEN $_{t-1}^{2}$ & & & & & & & & & $\begin{array}{l}-0.012 \\
(4.60)^{* * *}\end{array}$ & $\begin{array}{l}-0.016 \\
(4.58)^{* * *}\end{array}$ & $\begin{array}{l}-0.007 \\
(2.24)^{* *}\end{array}$ & $\begin{array}{l}-0.006 \\
(3.11)^{* * *}\end{array}$ \\
\hline Intercept & $\begin{array}{l}8.284 \\
(2.34)^{* * *}\end{array}$ & $\begin{array}{l}-6.139 \\
(1.33)\end{array}$ & $\begin{array}{l}14.249 \\
(3.47)^{* * * *}\end{array}$ & $\begin{array}{l}38.033 \\
(16.61)^{* * *}\end{array}$ & $\begin{array}{l}0.118 \\
(0.03)\end{array}$ & $\begin{array}{l}-18.161 \\
(3.18)^{* * *}\end{array}$ & $\begin{array}{l}10.617 \\
(2.11)^{* *}\end{array}$ & $\begin{array}{l}36.209 \\
(12.66)^{* * *}\end{array}$ & $\begin{array}{l}9.051 \\
(2.56)^{* *}\end{array}$ & $\begin{array}{l}-5.117 \\
(1.11)\end{array}$ & $\begin{array}{l}14.816 \\
(3.60)^{* * *}\end{array}$ & $\begin{array}{l}38.206 \\
(16.71)^{* * * *}\end{array}$ \\
\hline Control variables & Yes & Yes & Yes & Yes & Yes & Yes & Yes & Yes & Yes & Yes & Yes & Yes \\
\hline Year dummies & Yes & Yes & Yes & Yes & Yes & Yes & Yes & Yes & Yes & Yes & Yes & Yes \\
\hline Sector dummies & Yes & Yes & Yes & Yes & Yes & Yes & Yes & Yes & Yes & Yes & Yes & Yes \\
\hline Observations & 1724 & 1724 & 1724 & 1724 & 1724 & 1724 & 1724 & 1724 & 1724 & 1724 & 1724 & 1724 \\
\hline $\mathrm{R}$-squared & 0.407 & 0.340 & 0.368 & 0.324 & 0.410 & 0.343 & 0.371 & 0.325 & 0.407 & 0.340 & 0.367 & 0.324 \\
\hline \# Firms & 199 & 199 & 199 & 199 & 199 & 199 & 199 & 199 & 199 & 199 & 199 & 199 \\
\hline
\end{tabular}

$t$ statistics in parentheses and ${ }^{*} p<0.1,{ }^{* *} p<0.05,{ }^{* * *} p<0.01$. Appendix for variables definitions.

Panel C (continued)

Second Stage Regression: Quadratic Regression of Board Networks on ESG

\begin{tabular}{|c|c|c|c|c|c|c|c|c|}
\hline & ESG & ENV & SOC & GOV & ESG & ENV & SOC & GOV \\
\hline BETWEEN $_{\mathrm{t}-1}$ & $\begin{array}{l}0.774 \\
(2.76) * * *\end{array}$ & $\begin{array}{l}1.117 \\
(3.01)^{* * *}\end{array}$ & $\begin{array}{l}-0.562 \\
(2.24)^{* *}\end{array}$ & $\begin{array}{l}0.501 \\
(2.59) * * *\end{array}$ & & & & \\
\hline BETWEEN $_{\mathrm{t}-1^{2}}$ & $\begin{array}{l}-0.074 \\
(1.94)^{*}\end{array}$ & $\begin{array}{l}-0.133 \\
(2.68) * * *\end{array}$ & $\begin{array}{l}0.110 \\
(3.37)^{* * * *}\end{array}$ & $\begin{array}{l}-0.037 \\
(1.44)\end{array}$ & & & & \\
\hline $\mathrm{INFO}_{\mathrm{t}-1}$ & & & & & $\begin{array}{l}1.433 \\
(2.58)^{* * *}\end{array}$ & $\begin{array}{l}2.103 \\
(2.69) * * *\end{array}$ & $\begin{array}{l}0.966 \\
(1.16)\end{array}$ & $\begin{array}{l}1.687 \\
(2.55)^{* * *}\end{array}$ \\
\hline $\mathrm{INFO}_{\mathrm{t}-1}{ }^{2}$ & & & & & $\begin{array}{l}-0.224 \\
(2.41)^{* *}\end{array}$ & $\begin{array}{l}-0.333 \\
(2.55)^{* *}\end{array}$ & $\begin{array}{l}-0.167 \\
(1.20)\end{array}$ & $\begin{array}{l}-0.148 \\
(1.03)\end{array}$ \\
\hline Intercept & $\begin{array}{l}9.015 \\
(2.55)^{* *}\end{array}$ & $\begin{array}{l}-5.149 \\
(1.12)\end{array}$ & $\begin{array}{l}38.546 \\
(8.88)^{* * *}\end{array}$ & $\begin{array}{l}38.144 \\
(16.74)^{* * *}\end{array}$ & $\begin{array}{l}35.730 \\
(10.33)^{* * *}\end{array}$ & $\begin{array}{l}25.703 \\
(5.53)^{* * *}\end{array}$ & $\begin{array}{l}37.557 \\
(8.52)^{* * *}\end{array}$ & $\begin{array}{l}39.345 \\
(15.99) * * *\end{array}$ \\
\hline Control variables & Yes & Yes & Yes & Yes & Yes & Yes & Yes & Yes \\
\hline Year dummies & Yes & Yes & Yes & Yes & Yes & Yes & Yes & Yes \\
\hline Sector dummies & Yes & Yes & Yes & Yes & Yes & Yes & Yes & Yes \\
\hline Observations & 1724 & 1724 & 1724 & 1724 & 1724 & 1724 & 1724 & 1724 \\
\hline R-squared & 0.405 & 0.339 & 0.368 & 0.323 & 0.404 & 0.337 & 0.367 & 0.327 \\
\hline \# Firms & 199 & 199 & 199 & 199 & 199 & 199 & 199 & 199 \\
\hline
\end{tabular}

